Prepared in cooperation with the Missouri Department of Natural Resources

\title{
Quality of Surface Water in Missouri, Water Year 2010
}

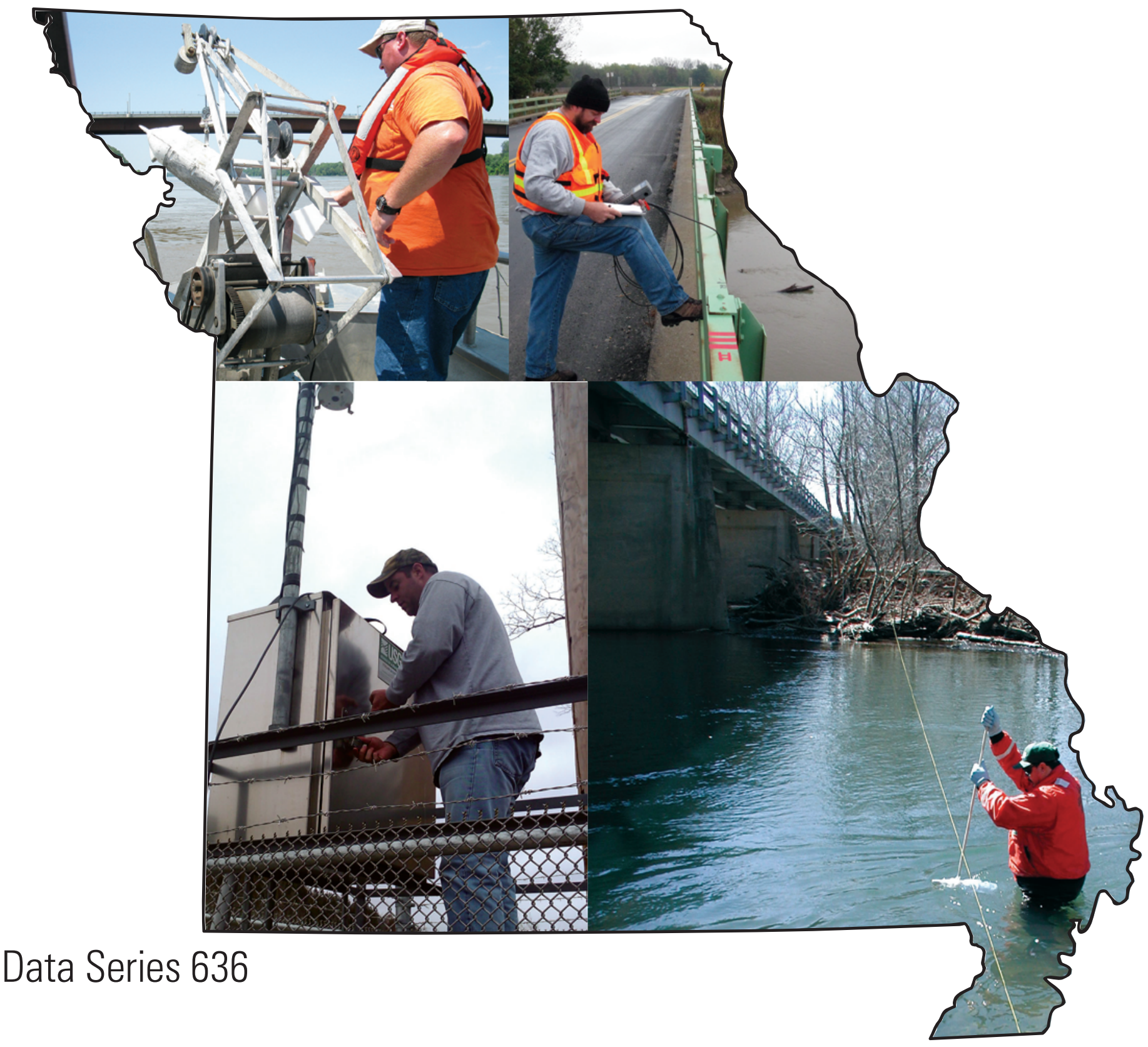

U.S. Department of the Interior

U.S. Geological Survey 


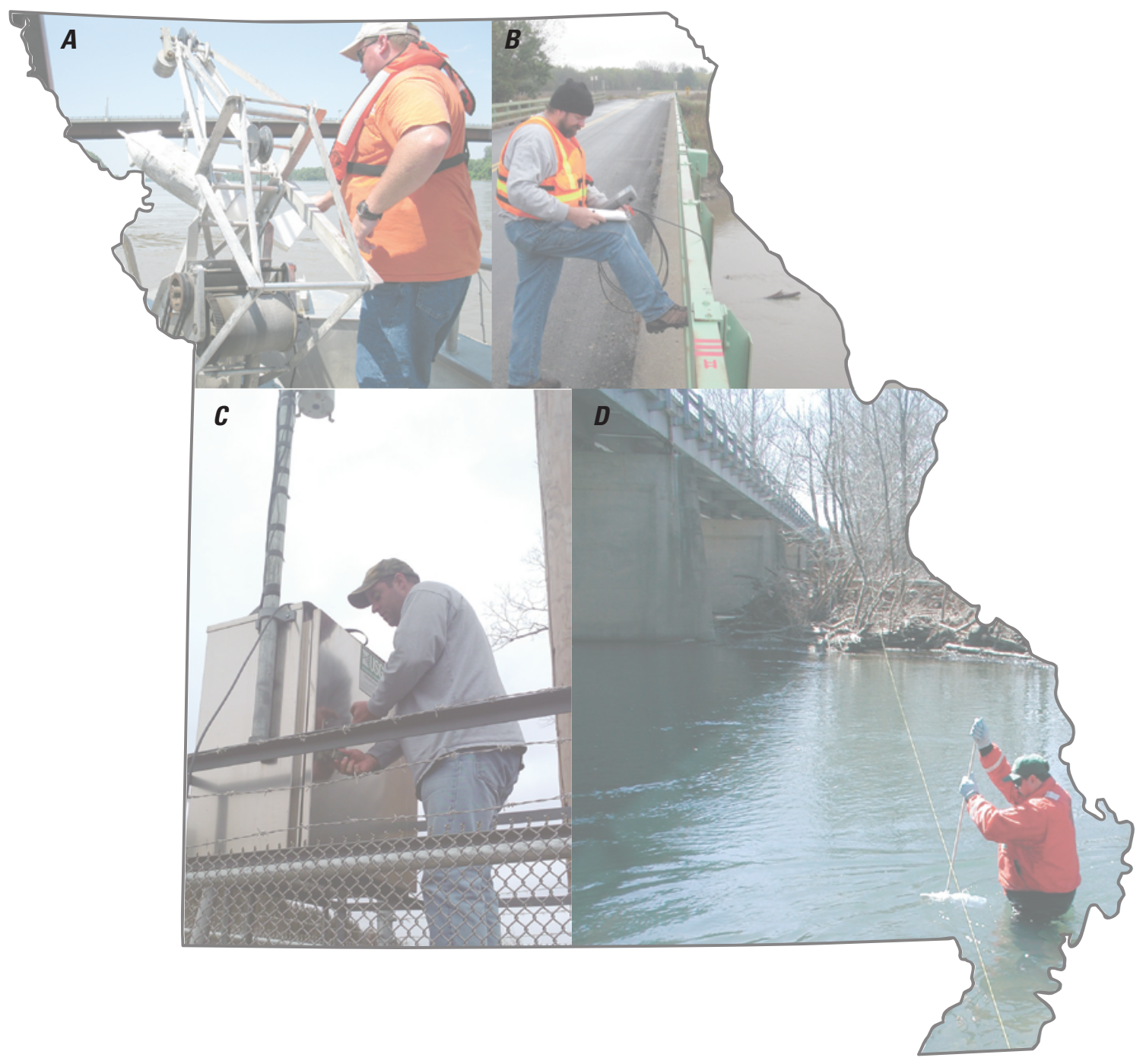

Cover. A, Hydrologic technician operating a U.S. Geological Survey D-96 surface-water sampler from a motorized boat. $B$, Hydrologic technician collecting physical properties from a bridge deck. $C$, Hydrologic technician servicing streamflow-gaging station equipment. $D$, Hydrologic technician collecting a surface-water quality sample using a U.S. Geological Survey DH-81 sampler. 


\section{U.S. Department of the Interior \\ KEN SALAZAR, Secretary \\ U.S. Geological Survey \\ Marcia K. McNutt, Director}

U.S. Geological Survey, Reston, Virginia: 2011

For more information on the USGS — the Federal source for science about the Earth, its natural and living resources, natural hazards, and the environment, visit http://www.usgs.gov or call 1-888-ASK-USGS.

For an overview of USGS information products, including maps, imagery, and publications, visit http://www.usgs.gov/pubprod

To order this and other USGS information products, visit http://store.usgs.gov

Any use of trade, product, or firm names is for descriptive purposes only and does not imply endorsement by the U.S. Government.

Although this report is in the public domain, permission must be secured from the individual copyright owners to reproduce any copyrighted materials contained within this report.

Suggested citation:

Barr, M.N., 2011, Quality of surface water in Missouri, water year 2010: U.S. Geological Survey Data Series 636, 21 p. 


\section{Contents}

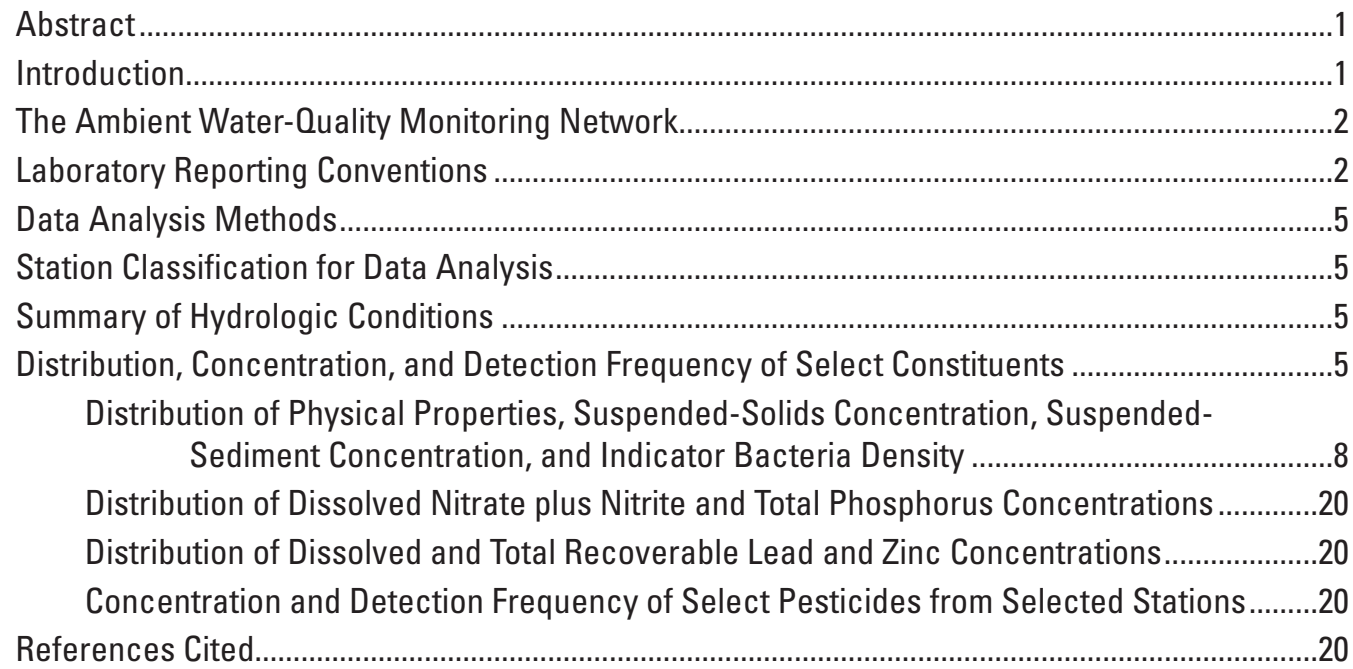

\section{Figures}

1. Map showing location and class of selected stations and physiographic regions

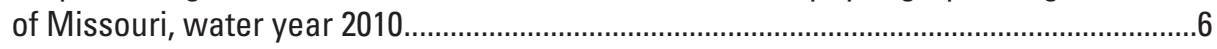

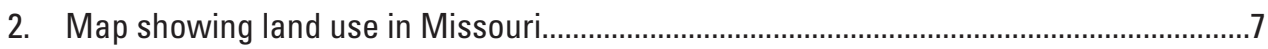

3. Graphs showing the 2010 water year monthly mean discharge and long-term median of monthly mean discharges at six representative streamgages .........................9

4. Boxplots showing distribution of physical properties, suspended solids, suspended sediment, and indicator bacteria densities in samples from 72 stations, water year 2010.

5. Boxplots showing concentration distribution of dissolved nitrate plus nitrite and total dissolved phosphorus in samples from 72 stations, water year $2010 \ldots \ldots \ldots \ldots \ldots \ldots \ldots . . . . .13$

6. Boxplots showing concentration distribution of dissolved and total recoverable lead and zinc in samples from 72 stations, water year 2010

7. Graphs showing detection of select pesticides from selected stations, water year 2010 


\section{Tables}

1. U.S. Geological Survey (USGS) station number, name, drainage area, and sampling frequency of 72 selected stations, water year 2010

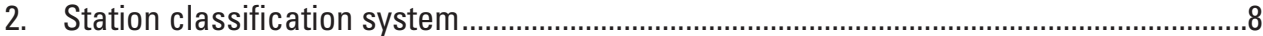

3. Peak discharge for the 2010 water year and select periods of record for selected streamgages

4. Seven-day low flow for water year 2010, period of record 7-day low flow, and period of record minimum daily mean flow for selected streamgages in Missouri

\section{Conversion Factors and Datum}

Inch/Pound to SI

\begin{tabular}{lll}
\hline \multicolumn{1}{c}{ Multiply } & By & \multicolumn{1}{c}{ To obtain } \\
\hline inch (in.) & Length & centimeter $(\mathrm{cm})$ \\
mile (mi) & 2.54 & kilometer $(\mathrm{km})$ \\
\hline & 1.609 & \\
\hline square mile $\left(\mathrm{mi}^{2}\right)$ & Area & square kilometer $\left(\mathrm{km}^{2}\right)$ \\
\hline & 2.590 & \\
\hline cubic foot per second $\left(\mathrm{ft}^{3} / \mathrm{s}\right)$ & Flow rate & cubic meter per second $\left(\mathrm{m}^{3} / \mathrm{s}\right)$ \\
\hline
\end{tabular}

SI to Inch/Pound

\begin{tabular}{lccc}
\hline & Multiply & By & To obtain \\
\hline & Volume & \\
\hline liter (L) & 0.2642 & gallon (gal) \\
\hline
\end{tabular}

Temperature in degrees Celsius $\left({ }^{\circ} \mathrm{C}\right)$ may be converted to degrees Fahrenheit $\left({ }^{\circ} \mathrm{F}\right)$ as follows:

$$
{ }^{\circ} \mathrm{F}=\left(1.8 x^{\circ} \mathrm{C}\right)+32
$$

Horizontal coordinate information is referenced to the North American Datum of 1983 (NAD 83).

Specific conductance is given in microsiemens per centimeter at 25 degrees Celsius $(\mu \mathrm{S} / \mathrm{cm}$ at $\left.25^{\circ} \mathrm{C}\right)$.

Concentrations of chemical constituents in water are given either in milligrams per liter (mg/L) or micrograms per liter $(\mu \mathrm{g} / \mathrm{L})$ 


\title{
Quality of Surface Water in Missouri, Water Year 2010
}

\author{
By Miya N. Barr
}

\section{Abstract}

The U.S. Geological Survey, in cooperation with the Missouri Department of Natural Resources, designs and operates a series of monitoring stations on streams throughout Missouri known as the Ambient Water-Quality Monitoring Network. During the 2010 water year (October 1, 2009 through September 30, 2010), data were collected at 75 stations - 72 Ambient Water-Quality Monitoring Network stations, 2 U.S. Geological Survey National Stream Quality Accounting Network stations, and 1 spring sampled in cooperation with the U.S. Forest Service. Dissolved oxygen, specific conductance, water temperature, suspended solids, suspended sediment, fecal coliform bacteria, Escherichia coli bacteria, dissolved nitrate plus nitrite, total phosphorus, dissolved and total recoverable lead and zinc, and select pesticide compound summaries are presented for 72 of these stations. The stations primarily have been classified into groups corresponding to the physiography of the State, primary land use, or unique station types. In addition, a summary of hydrologic conditions in the State including peak discharges, monthly mean discharges, and 7-day low flow is presented.

\section{Introduction}

The U.S. Geological Survey (USGS), in cooperation with the Missouri Department of Natural Resources (MDNR), collects data pertaining to Missouri's water resources each water year (October 1 through September 30). These data, stored and maintained in the USGS National Water Information System (NWIS) database, are collected as part of the Missouri Ambient Water-Quality Monitoring Network (AWQMN) and constitute a source of reliable, impartial, and timely information for developing an enhanced understanding of the State's water resources. To make this information readily available, these data were published annually from water years 1964 through 2005 (U.S. Geological Survey, 1964-2005). Published data for the 2006 through 2010 water years can be accessed at $h t t p: / / w d r$.water.usgs.gov.
The MDNR is responsible for the implementation of the Federal Clean Water Act (CWA) in Missouri. Section 305(b) of the CWA requires that each State develop a water-quality monitoring program and periodically report the status of its water quality (U.S. Environmental Protection Agency, 1997). Water-quality status is described in terms of the suitability of the water for various uses, such as drinking, fishing, swimming, and support of aquatic life; these uses are formally defined as "designated uses" in State and Federal Regulations. Section 303(d) of the CWA requires that certain waters that do not meet applicable water-quality standards be identified, and total maximum daily loads (TMDLs) be determined for these waters (U.S. Environmental Protection Agency, 1997). TMDLs establish the maximum amount of an impairing substance that a waterbody can assimilate and still meet the water- quality standards. A TDML addresses a single pollutant for each waterbody.

Missouri has an area of approximately 69,000 square miles $\left(\mathrm{mi}^{2}\right)$ and an estimated population of 6 million people (U.S. Census Bureau, 2010). Within Missouri there are 22,708 miles (mi) of classified streams that support a variety of uses including wildlife, recreation, agriculture, industry, transportation, and public utilities. An estimated 11,646 mi of streams are adversely affected (impaired) by various physical changes or chemical contaminants to the point that criteria for at least one of the designated uses no longer can be met (Missouri Department of Natural Resources, 2010a). Of the impaired streams, about 3,772 mi have been sampled, and the impairments are documented by data that meet Missouri's 303(d) Listing Methodology. There also are about 7,874 mi of classified streams deemed unassessed, for which some data have been collected but not enough to officially rate the stream as impaired. Many of the unassessed streams have been affected or modified by agriculture (Missouri Department of Natural Resources, 2010a).

The purpose of this report is to summarize surfacewater quality data collected by the USGS in cooperation with the MDNR and other Federal and local entities for water year 2010. The annual summary of select constituents provides MDNR with current information to assess the quality of surface water within the State and to ensure that the objectives of the 
AWQMN are being met. This report is one in a series of annual summaries (Otero-Benítez and Davis, 2009a, 2009b, Barr, 2010). Data on the physical characteristics and water-quality constituents in samples collected at 72 surface-water stations are presented in figures and tables. These 72 stations primarily were classified into groups corresponding to the physiography of the State, primary land use, or unique station types.

\section{The Ambient Water-Quality Monitoring Network}

The USGS, in cooperation with the MDNR, designed and operates the cooperative AWQMN, which is a series of monitoring stations on streams and springs throughout Missouri. Constituent concentration data from the AWQMN have been used to determine statewide water-quality status and long-term trends (Barr and Davis, 2010) in order to meet information needs of State agencies involved in water-quality planning and management. The data collected also provide support for the design, implementation, and evaluation of preventive and remediation programs.

The objectives of the AWQMN are (1) to obtain data on the quality and quantity of surface water within the State; (2) provide a historical database of water-quality information that can be used by the State planning and management agencies to make informed decisions about anthropogenic effects (agriculture, mining, urban) on the State's surface waters; and (3) provide for consistent methodology in data collection, laboratory analysis, and data reporting.

The MDNR and the USGS established a fixed-station AWQMN in 1964 with 18 stations, 5 of which are still currently (2011) being sampled. During the 2010 water year, the program consisted of 72 stations. In addition to the AWQMN stations, water samples are collected by the USGS at two USGS National Stream Quality Accounting Network (NASQAN; a national water-quality sampling network operated by the USGS) stations, and one spring sampled in cooperation with the U.S. Forest Service. From these 75 stations, 72 are included in this report. There were three stations from the AWQMN did not fit in the groups (classes) defined for this report and were not included. The three excluded stations were Cuivre River near Troy (05514500) and Lamine River near Pilot Grove (06907300) both located in the Ozark Plateaus border, and Lake Taneycomo at Branson (07053700). Sampling frequency (table 1) is determined by a number of factors, including drainage basin size, potential effects from anthropogenic activities (such as, agriculture, mining and urban), history of chemical change, need for short-term data, and cost. Each of the streams in the AWQMN is classified for one or more designated uses. For specific information on the designated uses applicable to the stations in the AWQMN, refer to Missouri Department of Natural Resources (2010b).
The unique eight-digit number used by the USGS to identify each surface-water station is assigned when a station is first established. The complete eight-digit number for each station includes a two-digit prefix that designates the major river system (05 is the Upper Mississippi River, 06 is the Missouri River, and 07 is the Lower Mississippi River) plus a six-digit downstream-order number. For example, the station number 05587455 indicates the station is located on the Upper Mississippi River ("05") while the remaining six digits ("587455") locate the station in downstream order. In this system, the station numbers increase downstream along the main stem. A station on a tributary that enters between two main stem stations is assigned a station number between them.

Methods used for collecting and processing representative water-quality samples are presented in detail in the USGS National Field Manual for the Collection of WaterQuality Data (U.S. Geological Survey, variously dated). Onsite measurements of dissolved oxygen (DO), specific conductance, and water temperature were taken at each station according to procedures described in Wilde (chapter sections variously dated). Samples were collected and analyzed for indicator bacteria [Escherichia coli (E. coli)] and fecal coliform] using the membrane filtration procedure described in Myers and others (2007). Methods used by the USGS for collecting and processing representative samples for nutrients, major chemical constituents, trace elements, suspended solids, suspended sediment, and pesticide analysis are presented in detail in U.S. Geological Survey (2006), Guy (1969), and Wilde and others (2004). All chemical analyses were done by the USGS National Water Quality Laboratory (NWQL) in Lakewood, Colorado, according to procedures described in Fishman and Friedman (1989), Fishman (1993), and Zaugg and others (1995).

\section{Laboratory Reporting Conventions}

The NWQL uses method reporting conventions (Childress and others, 1999) for establishing the minimum concentration for more than which a quantitative measurement can be made. These reporting conventions are the method reporting level (MRL) and the laboratory reporting level (LRL). The MRL is defined by the NWQL as the smallest measured concentration of a substance that can be measured reliably using a given analytical method. The method detection level (MDL) is the minimum concentration of a substance that can be measured and reported with 99-percent confidence that the concentration is greater than zero. A long-term method detection level (LT-MDL) is a detection level obtained by determining the standard deviation of 20 or more MDL spiked-sample measurements conducted for an extended period of time. The LRL is computed as twice the LT-MDL. 
Table 1. U.S. Geological Survey (USGS) station number, name, drainage area, and sampling frequency of 72 selected stations, water year 2010.

[mi², square mile; --, not applicable]

\begin{tabular}{|c|c|c|c|}
\hline $\begin{array}{c}\text { USGS } \\
\text { station number }\end{array}$ & Station name & $\begin{array}{c}\text { Drainage area } \\
\qquad\left(\mathrm{mi}^{2}\right)\end{array}$ & $\begin{array}{c}\text { Water year } 2010 \\
\text { sampling frequency }\end{array}$ \\
\hline 05495000 & Fox River at Wayland, Mo. & 400 & 6 \\
\hline 05496000 & Wyaconda River above Canton, Mo. & 393 & 6 \\
\hline 05497150 & North Fabius River near Ewing, Mo. & 471 & 6 \\
\hline 05500000 & South Fabius River near Taylor, Mo. & 620 & 12 \\
\hline 05587455 & Mississippi River below Grafton, Ill. & 171,300 & 12 \\
\hline 06817700 & Nodaway River near Graham, Mo. & 1,380 & 6 \\
\hline${ }^{\mathrm{a}} 06818000$ & Missouri River at St. Joseph, Mo. & 420,100 & 12 \\
\hline 06821190 & Platte River at Sharps Station, Mo. & 2,380 & 6 \\
\hline 06894100 & Missouri River at Sibley, Mo. & 426,500 & 12 \\
\hline 06896187 & Middle Fork Grand River near Grant City, Mo. & 82.4 & 6 \\
\hline 06898100 & Thompson River at Mt. Moriah, Mo. & 891 & 6 \\
\hline 06898800 & Weldon River near Princeton, Mo. & 452 & 6 \\
\hline 06899580 & No Creek near Dunlap, Mo. & 34 & 12 \\
\hline 06899950 & Medicine Creek near Harris, Mo. & 192 & 12 \\
\hline 06900100 & Little Medicine Creek near Harris, Mo. & 66.5 & 12 \\
\hline 06900900 & Locust Creek near Unionville, Mo. & 77.5 & 12 \\
\hline 06902000 & Grand River near Sumner, Mo. & 6,880 & 12 \\
\hline 06905500 & Chariton River near Prairie Hill, Mo. & 1,870 & 6 \\
\hline 06905725 & Mussel Fork near Mystic, Mo. & 24 & 12 \\
\hline 06906300 & East Fork Little Chariton River near Huntsville, Mo. & 220 & 6 \\
\hline 06917630 & East Drywood Creek at Prairie State Park, Mo. & 3.38 & 6 \\
\hline 06918070 & Osage River above Schell City, Mo. & 5,410 & 6 \\
\hline 06918600 & Little Sac River near Walnut Grove, Mo. & 119 & 12 \\
\hline 06919500 & Cedar Creek near Pleasant View, Mo. & 420 & 12 \\
\hline 06921070 & Pomme de Terre River near Polk, Mo. & 276 & 9 \\
\hline 06921590 & South Grand River at Archie, Mo. & 150 & 6 \\
\hline 06921720 & Big Creek near Blairstown, Mo. & 414 & 12 \\
\hline 06923700 & Niangua River at Bennett Spring, Mo. & 441 & 6 \\
\hline 06926510 & Osage River below St. Thomas, Mo. & 14,580 & 6 \\
\hline 06927850 & Osage Fork of the Gasconade River near Lebanon, Mo. & 43.6 & 6 \\
\hline 06928440 & Roubidoux Spring at Waynesville, Mo. & -- & 6 \\
\hline 06930450 & Big Piney River at Devil's Elbow, Mo. & 746 & 9 \\
\hline 06930800 & Gasconade River above Jerome, Mo. & 2,570 & 12 \\
\hline a,b 06934500 & Missouri River at Hermann, Mo. & 522,500 & 12 \\
\hline 07014000 & Huzzah Creek near Steelville, Mo. & 259 & 6 \\
\hline 07014200 & Courtois Creek at Berryman, Mo. & 173 & 6 \\
\hline 07014500 & Meramec River near Sullivan, Mo. & 1,475 & 12 \\
\hline
\end{tabular}


Quality of Surface Water in Missouri, Water Year 2010

Table 1. U.S. Geological Survey (USGS) station number, name, drainage area, and sampling frequency of 72 selected stations, water year 2010.-Continued

$\left[\mathrm{mi}^{2}\right.$, square mile; --, not applicable]

\begin{tabular}{|c|c|c|c|}
\hline $\begin{array}{c}\text { USGS } \\
\text { station number }\end{array}$ & Station name & $\begin{array}{c}\text { Drainage area } \\
\left(\mathrm{mi}^{2}\right)\end{array}$ & $\begin{array}{c}\text { Water year } 2010 \\
\text { sampling frequency }\end{array}$ \\
\hline 07016400 & Bourbeuse River above Union, Mo. & 808 & 9 \\
\hline 07018100 & Big River near Richwoods, Mo. & 735 & 9 \\
\hline 07019280 & Meramec River at Paulina Hills, Mo. & 3,920 & 12 \\
\hline 07020550 & South Fork Saline Creek near Perryville, Mo. & 55.3 & 6 \\
\hline 07021000 & Castor River at Zalma, Mo. & 423 & 6 \\
\hline${ }^{\mathrm{a}} 07022000$ & Mississippi River at Thebes, Ill. & 713,200 & 12 \\
\hline 07036100 & St. Francis River near Saco, Mo. & 664 & 9 \\
\hline 07037300 & Big Creek at Sam A. Baker State Park, Mo. & 189 & 6 \\
\hline 07042450 & St. Johns Ditch at Henderson Mound, Mo. & 313 & 9 \\
\hline 07046250 & Little River Ditches near Rives, Mo. & 1,620 & 12 \\
\hline 07050150 & Roaring River Spring at Cassville, Mo. & -- & 6 \\
\hline 07052152 & Wilson Creek near Brookline, Mo. & 51 & 12 \\
\hline 07052250 & James River near Boaz, Mo. & 462 & 6 \\
\hline 07052345 & Finley Creek below Riverdale, Mo. & 261 & 12 \\
\hline 07052500 & James River at Galena, Mo. & 987 & 12 \\
\hline 07052820 & Flat Creek below Jenkins, Mo. & 274 & 12 \\
\hline 07053900 & Swan Creek near Swan, Mo. & 148 & 6 \\
\hline 07057500 & North Fork River near Tecumseh, Mo. & 561 & 6 \\
\hline 07057750 & Bryant Creek below Evans, Mo. & 214 & 6 \\
\hline 07061600 & Black River below Annapolis, Mo. & 493 & 6 \\
\hline 07066110 & Jacks Fork above Two Rivers, Mo. & 425 & 12 \\
\hline 07067500 & Big Spring near Van Buren, Mo. & -- & 4 \\
\hline 07068000 & Current River at Doniphan, Mo. & 2,040 & 12 \\
\hline 07068510 & Little Black River below Fairdealing, Mo. & 194 & 6 \\
\hline${ }^{\mathrm{b}} 07071000$ & Greer Spring at Greer, Mo. & -- & 4 \\
\hline 07071500 & Eleven Point River near Bardley, Mo. & 793 & 6 \\
\hline 07185764 & Spring River above Carthage, Mo. & 425 & 12 \\
\hline 07186480 & Center Creek near Smithfield, Mo. & 303 & 9 \\
\hline 07186600 & Turkey Creek near Joplin, Mo. & 41.8 & 9 \\
\hline 07187000 & Shoal Creek above Joplin, Mo. & 427 & 12 \\
\hline 07188653 & Big Sugar Creek near Powell, Mo. & 141 & 12 \\
\hline 07188838 & Little Sugar Creek near Pineville, Mo. & 195 & 12 \\
\hline 07188885 & Indian Creek near Lanagan, Mo. & 239 & 12 \\
\hline 07189000 & Elk River near Tiff City, Mo. & 872 & 12 \\
\hline 07189100 & Buffalo Creek at Tiff City, Mo. & 60.8 & 12 \\
\hline
\end{tabular}

${ }^{a}$ Additional water temperature and suspended-sediment samples were collected in cooperation with the U.S. Army Corps of Engineers.

${ }^{\mathrm{b}}$ Stations 06934500, 07022000, 07071000 are not part of the Ambient Water-Quality Monitoring Network (AWQMN), but were used in the report. Stations 06934500 and 07022000 are funded by the U.S. Geological Survey National Stream Quality Accounting Network (NASQAN); 07071000 is funded by the U.S. Forest Service. 


\section{Data Analysis Methods}

The distribution of select constituent data was graphically displayed using side-by-side boxplots (box and whiskers distributions; Helsel and Hirsch, 2002, p. 24-26). The plots show the center of the data (median, the center line of the boxplot), the variation [interquartile range (25th to 75 th percentiles) or the height of the box], the skewness (quartile skew, which is the relative size of the box halves), the spread (upper and lower adjacent values are the vertical lines or whskers), and the presence or absence of unusual values, or outliers (upper and lower detached and outside values). If the median equals the 25th and 75th percentiles, the boxplot is represented by a single horizontal line. Censored data defined as concentration values reported less than the MRL, less than the LRL, or as "E" (estimated to be below the MRL or LRL) were included in each distribution as a concentration value equal to the MRL or LRL, depending on the constituent reporting convention. Boxplots with censored data were modified by making the lower limit of the box equal to the MRL or LRL.

\section{Station Classification for Data Analysis}

The stations primarily were classified in groups corresponding to the physiography of the State (fig. 1), primary land use (fig. 2), or unique station types (fig. 1; table 2). The physiography-based groups include the Dissected Till Plains (DTPL) in the north, the Osage Plains (OSPL) in the west, the Mississippi Alluvial Plain (MIALPL) in the southeast, and between them the Ozark Plateaus. The Ozark Plateaus (Fenneman, 1938) were further subdivided into two distinct groups based on physiographic location - the Salem Plateau (OZPLSA) and the Springfield Plateau (OZPLSP). Landuse groups include mining (MINING) and urban (URBAN) stations, whereas unique station classes refer to springs (SPRING) and the stations located on the big rivers [the Mississippi River (BRMIG and BRMIT) and the Missouri River (BRMOSJ, BRMOS and BRMOH)].

Some additional variability caused by differences in drainage area and land use was observed within physiographic regions; therefore, watershed size and land-use indicators were employed to develop a complete set of classes. The land-use indicator provides a subclassification for stations in similar regions with different land uses (fig. 1; table 2). The secondary land-use indicators are watershed indicator stations (wi), which are the most downstream stations in a large watershed, and are defined for the purposes of this report as a drainage area greater than 1,000 $\mathrm{mi}^{2}$; forest (fo); agricultural (ag); and prairie (pr). Observations and analyses from watershed indicator stations can be interpreted as being representative of the general condition of the watershed. In some instances, both the agricultural and forest secondary land uses were present; therefore, the convention was to mention them in predominant order. For example, an agriculture and forest (ag/fo) indicator implies that the primary land use of the watershed is agriculture, although a substantial portion of the land use is forest.

\section{Summary of Hydrologic Conditions}

Surface-water streamflow varies seasonally in Missouri and tends to reflect precipitation patterns. Six continuous streamflow-gaging stations (hereinafter referred to as streamgages) across the State were selected to illustrate the 2010 water year monthly mean discharge and the long-term median of monthly mean discharge (fig. 3). The selection of these streamgages was based on their geographical distribution across the State and their long period of record. Of these six stations, two (05495000 and 07052500) are part of the AWQMN, one (06934500) is a NASQAN station, and the remaining three $(06897500,06933500$, and 07067000$)$ are gaging stations only and are not part of the AWQMN.

During the 2010 water year, the average annual precipitation of the contiguous United States was about 1.02 inches (in.) more than the long-term average (National Oceanic and Atmospheric Administration, 2011a). Missouri experienced precipitation ranked more than normal with 55.9 in. of total precipitation (National Oceanic and Atmospheric Administration, 2011b). Monthly mean discharges were greater than or equal to the median of the monthly mean discharges for the period of record at all stations except 05495000 (Fox River at Wayland) during February, 06933500 (Gasconade River at Jerome) during August, and 07052500 (James River at Galena) during December, June, and August, and 07067000 (Current River at Van Buren) during March and April. The largest differences can be observed at stations 05495000 and 06897500 (Grand River near Gallatin; fig. 3).

Peak discharges for the 2010 water year and select periods of record are presented for nine streamgages (table 3) selected for their geographical distribution across the State and their long period of record. Although precipitation amounts recorded during the 2010 water year were more than average, the peak discharges shown in table 3 were less than the peak discharges for the period of record at all stations. The 7-day low flow for the period of record, and the minimum daily mean flow for the 2010 water year are presented for selected stations in table 4 .

\section{Distribution, Concentration, and Detection Frequency of Select Constituents}

The analyses presented in this report include the following constituents: dissolved oxygen (DO), specific conductance, water temperature, suspended solids, suspended sediment, E. coli bacteria, fecal coliform bacteria, dissolved nitrate plus nitrite, total phosphorus, and dissolved and total recoverable lead and zinc. In addition, pesticide data were analyzed from 


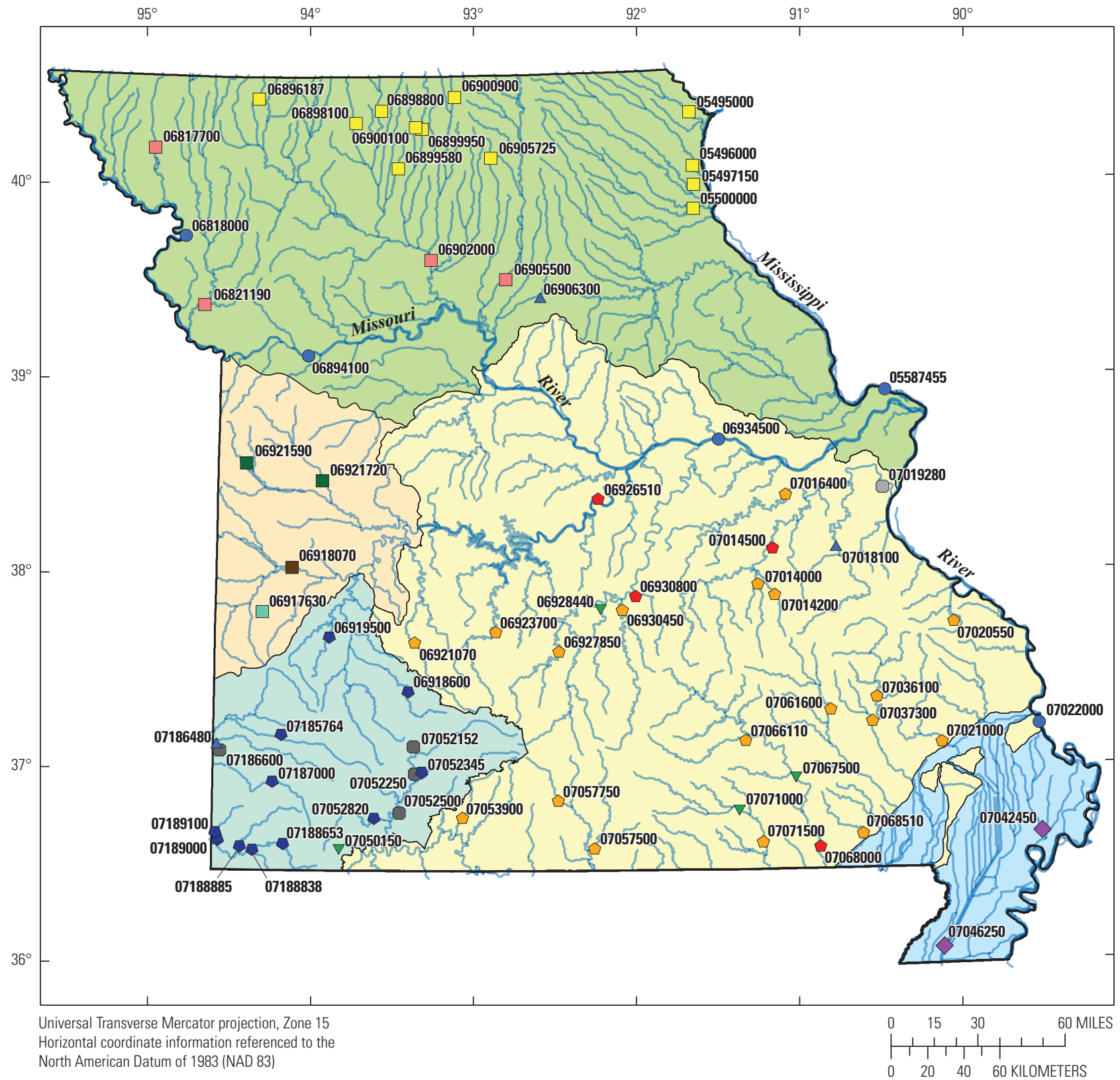

\section{EXPLANATION}

Physiographic regions of Missouri-Modified from Fenneman, 1938

$\square$ Central Lowland Province—Dissected Till Plains

Central Lowland Province-Osage Plains

Coastal Plain Province-Mississippi Alluvial Plain

Ozark Plateaus Province-Salem Plateau

Ozark Plateaus Province — Springfield Plateau

Ambient Water-Quality Monitoring Network (AWOMN) classes and station number (05500000)—Table 2

- Big River (BRMIG, BRMIT, BRMOSJ, BRMOS, and BRMOH)

$\checkmark \quad$ Mississippi Alluvial Plain (MIALPL)

$\square \quad$ Dissected Till Plains agriculture (DTPL ag)

$\square \quad$ Dissected Till Plains watershed indicator, agriculture (DTPL wi ag)

Osage Plains agriculture (OSPL ag)

- Osage Plains watershed indic ator, agriculture (OSPL wi ag)

$\square \quad$ 0sage Plains prairie (OSPL pr)

0zark Plateaus-Salem Plateau forest and agriculture (OZPLSA fo/ag)

Ozark Plateaus-Salem Plateau watershed indicator, forest and agriculture (OZPLSA wi fo/ag)

- Ozark Plateaus-Springfield Plateau agriculture and forest (OZPLSP ag/fo)

$\nabla \quad$ Springs (SPRING)

$\Delta \quad$ Mining (MINING)

- Urban (URBAN)

Urban watershed indicator (URBAN wi)

Figure 1. Location and class of selected stations and physiographic regions of Missouri, water year 2010. 


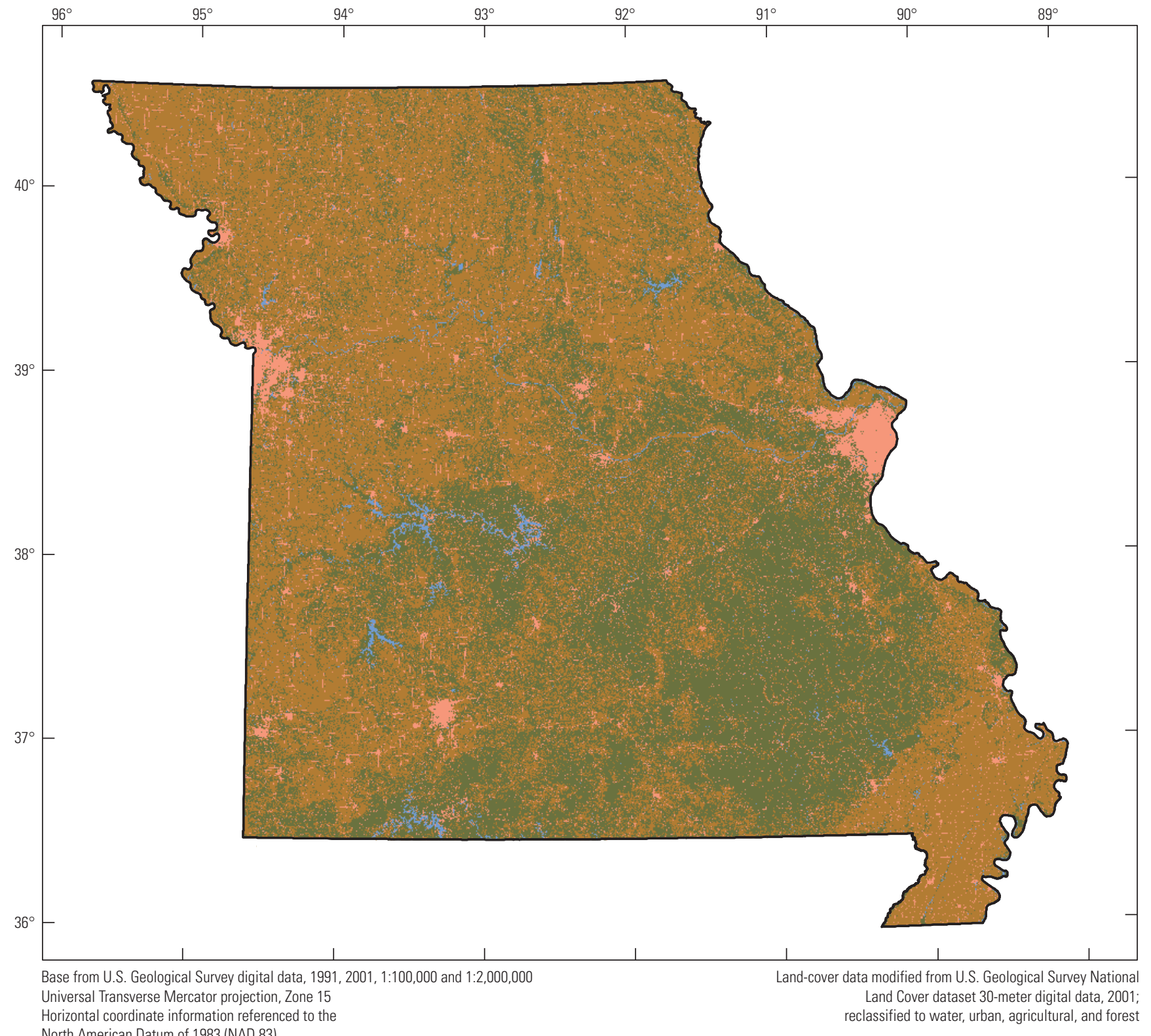

Horizontal coordinate information referenced to the North American Datum of 1983 (NAD 83)

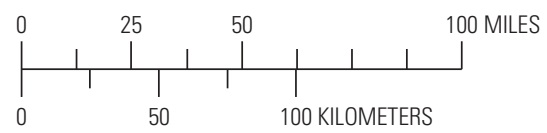

\section{EXPLANATION}

Open water (lakes)

Urban
Agricultural land

Forest

Figure 2. Land use in Missouri. 
Table 2. Station classification system.

\begin{tabular}{|c|c|c|}
\hline $\begin{array}{l}\text { Class } \\
\text { (fig. 1) }\end{array}$ & Description & $\begin{array}{l}\text { Number of } \\
\text { stations }\end{array}$ \\
\hline BRMIG & $\begin{array}{l}\text { Big River-Mississippi River } \\
\text { below Grafton, Ill. }\end{array}$ & 1 \\
\hline BRMIT & $\begin{array}{l}\text { Big River-Mississippi River at } \\
\text { Thebes, Ill. }\end{array}$ & 1 \\
\hline BRMOSJ & $\begin{array}{l}\text { Big River-Missouri River at } \\
\text { St. Joseph, Mo. }\end{array}$ & 1 \\
\hline BRMOS & $\begin{array}{l}\text { Big River-Missouri River at } \\
\text { Sibley, Mo. }\end{array}$ & 1 \\
\hline BRMOH & $\begin{array}{l}\text { Big River-Missouri River at } \\
\text { Hermann, Mo. }\end{array}$ & 1 \\
\hline MIALPL & Mississippi Alluvial Plain & ${ }^{\mathrm{a}} 2$ \\
\hline OZPLSA fo/ag & $\begin{array}{l}\text { Ozark Plateaus_-Salem Plateau } \\
\text { forest and agriculture }\end{array}$ & 18 \\
\hline OZPLSA wi fo/ag & $\begin{array}{l}\text { Ozark Plateaus_-Salem Plateau } \\
\text { watershed indicator, forest and } \\
\text { agriculture }\end{array}$ & 4 \\
\hline OZPLSP ag/fo & $\begin{array}{l}\text { Ozark Plateaus-Springfield } \\
\text { Plateau agriculture and forest }\end{array}$ & 11 \\
\hline DTPL ag & Dissected Till Plains agriculture & 12 \\
\hline DTPL wi ag & $\begin{array}{l}\text { Dissected Till Plains watershed } \\
\text { indicator, agriculture }\end{array}$ & 4 \\
\hline OSPL ag & Osage Plains agriculture & 2 \\
\hline OSPL wi ag & $\begin{array}{l}\text { Osage Plains watershed indicator, } \\
\text { agriculture }\end{array}$ & 1 \\
\hline OSPL pr & Osage Plains prairie & 1 \\
\hline SPRING & Springs & 4 \\
\hline MINING & Mining & 3 \\
\hline URBAN & Urban & 4 \\
\hline URBAN wi & Urban watershed indicator & 1 \\
\hline
\end{tabular}

${ }^{a}$ One station in this class, Little River Ditches near Rives, Mo. (07046250), has a drainage area greater than 1,000 square miles but is not considered a watershed indicator station because the manmade canals and ditches within its drainage area are not hydrologically connected.

eight stations. There were 16 pesticides selected for presentation in this report: 2-chloro-4-isopropylamino-6-amino-striazine (CIAT; a degradation product of atrazine), 3,4-dichloroaniline, 3,5-dichloroaniline, acetochlor, alachlor, atrazine, cis-propaconazole, dimethoate, metalaxyl, methyl paraoxon, methyl parathion, metoalachlor, metribuzin, prometryn, propanil, and simazine. The selection of these constituents and pesticides for presentation in this report was based on: (1) values or concentrations of the select constituents are characteristic of stream-water quality in the different physiographic areas, and (2) values and concentrations of the select constituents and pesticides are more than background concentrations. Boxplots of measured constituents are presented for the different classes (figs. 4-6). Pesticide data are presented in figure 7. Missouri water-quality standards are not shown on the graphs because these standards are not applicable to all streams in the AWQMN network. For specific information on Missouri water-quality standards, refer to Missouri Department of Natural Resources (2010b).

\section{Distribution of Physical Properties, Suspended- Solids Concentration, Suspended-Sediment Concentration, and Indicator Bacteria Density}

The physical properties analyzed for this report were DO, specific conductance, and water temperature. The median DO, in percent saturation, ranged from 76.5 to 104 percent (fig. 4). Samples from OZPLSA fo/ag, OZPLSP ag/fo, MINING, and URBAN stations had the highest median DO percent saturation values, whereas samples from MIALPL, OSPL wi ag, SPRING, and URBAN wi stations had the lowest median DO (fig. 4).

Median specific conductance values varied substantially among the station classes (fig. 4), ranging from 99 microsiemens per centimeter at 25 degrees Celsius at the OSPL pr station to 737 microsiemens per centimeter at 25 degrees Celsius at the Big River stations BRMOSJ and BRMOS. Median water temperature values ranged from 12.5 to 22.8 degrees Celsius, with the smallest median measured at OSPL ag stations and the largest median measured at the Big River station BRMOH (fig. 4). The range in water temperature at the SPRING stations was much smaller than at any other station class.

Suspended solids and suspended sediment are measures of the solid material suspended in the water column. These two measures are not considered directly comparable because of differences in collection and analytical techniques. Suspended-sediment concentrations were determined only at four Big River stations. Suspended-solids concentrations were determined at all stations except BRMIT and BRMOH. Median suspended-solids concentrations varied considerably between all station classes, ranging from less than 15 to 377 milligrams per liter $(\mathrm{mg} / \mathrm{L})$. Samples collected at the BRMIG, BRMOSJ, BRMOS, and DTPL wi ag stations had the largest median suspended-solids concentrations, whereas samples collected at the OZPL (SA fo/ag, SA wi fo/ag, and SP ag/fo), OSPL pr, SPRING, MINING, and URBAN stations had median concentrations less than the LRL. Median suspended-sediment concentrations ranged from $119 \mathrm{mg} / \mathrm{L}$ at BRMIG to $665 \mathrm{mg} / \mathrm{L}$ at BRMOSJ (fig. 4).

Median E. coli bacteria densities ranged from 7 to 1,800 colonies per 100 milliliters (col/100mL) (fig. 4). The largest median densities were in samples collected at BRMOS, whereas the lowest median densities were in samples collected at SPRING stations (fig. 4). Median fecal coliform bacteria densities (fig. 4) ranged from 9 to $2,000 \mathrm{col} / 100 \mathrm{~mL}$. The largest median densities were in samples collected at the BRMOS station; the smallest median densities were measured at SPRING stations. Median E. coli and fecal coliform bacteria densities varied considerably between all station classes. 
05495000 Fox River at Wayland

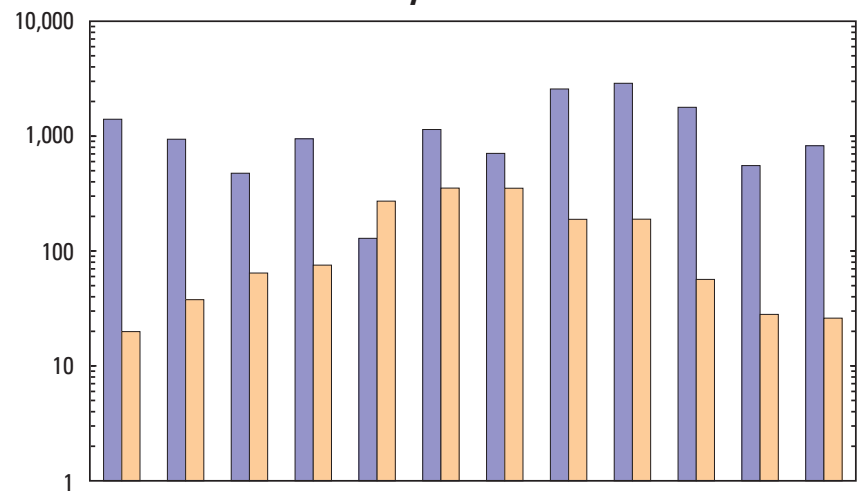

06933500 Gasconade River at Jerome

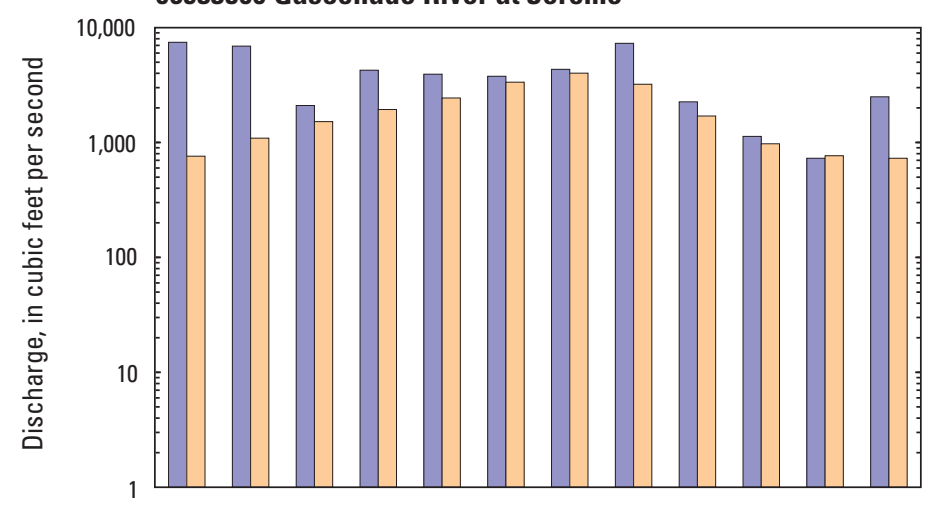

07052500 James River at Galena
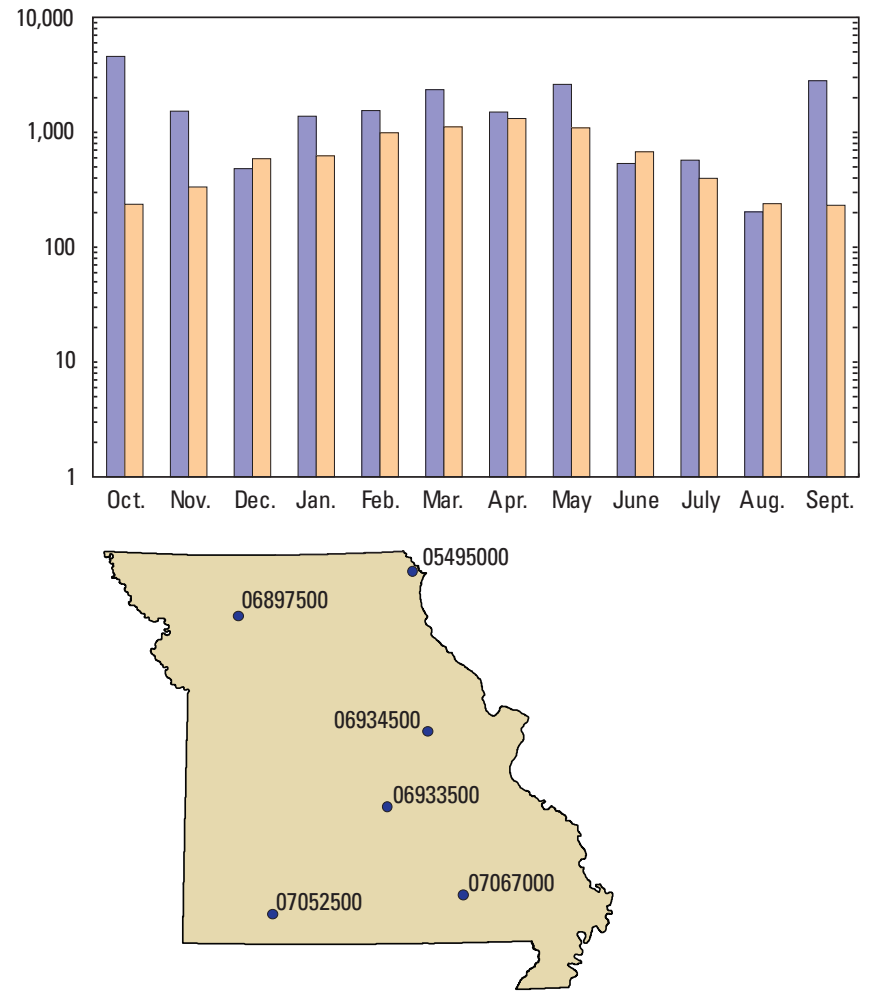

06897500 Grand River near Gallatin

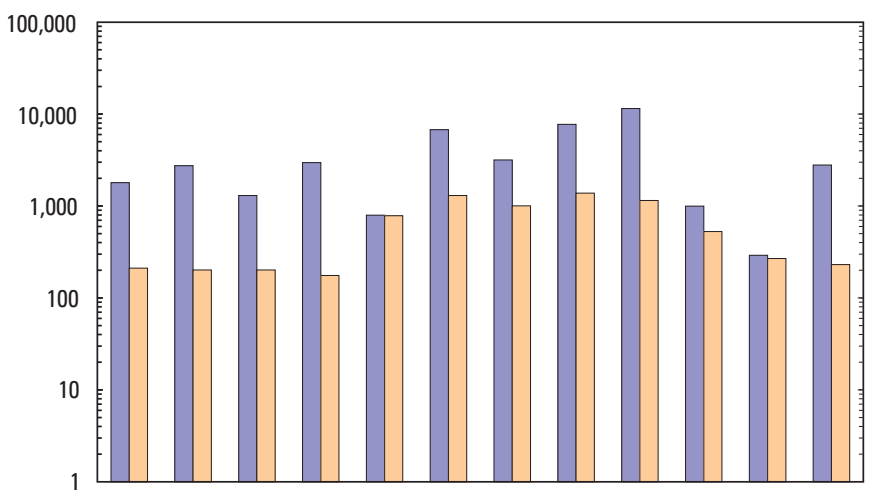

06934500 Missouri River at Hermann

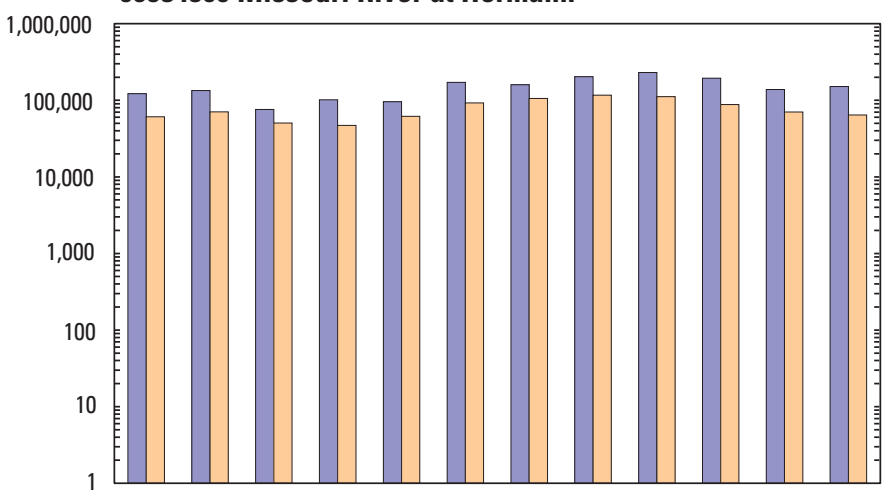

07067000 Current River at Van Buren

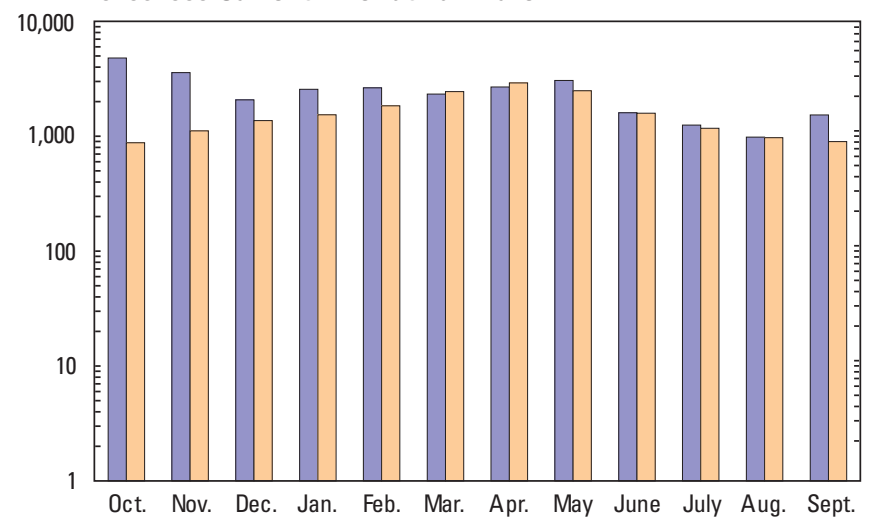

EXPLANATION

2010 water year monthly mean discharge

Median monthly mean discharge for period of record

Figure 3. The 2010 water year monthly mean discharge and long-term median of monthly mean discharges at six representative streamgages. 
Table 3. Peak discharge for the 2010 water year and select periods of record for selected streamgages.

[Peak discharge in cubic feet per second]

\begin{tabular}{|c|c|c|c|c|c|}
\hline \multirow{2}{*}{$\begin{array}{l}\text { U.S. Geological } \\
\text { Survey station } \\
\text { number }^{\mathrm{a}}\end{array}$} & \multirow{2}{*}{$\begin{array}{l}\text { Station name } \\
\text { (period of record used for statistical summaries } \\
\text { in water years) }\end{array}$} & \multicolumn{2}{|c|}{2010 water year } & \multicolumn{2}{|c|}{ Long-term period of record } \\
\hline & & $\begin{array}{c}\text { Peak } \\
\text { discharge }\end{array}$ & Date & $\begin{array}{c}\text { Peak } \\
\text { discharge }\end{array}$ & Date \\
\hline 05495000 & Fox River at Wayland, Mo. (1922-2010) & 13,800 & July 21 & 26,400 & Apr. 22, 1973 \\
\hline 05587450 & Mississippi River at Grafton, Ill. (1987-2010) & 372,000 & June 27, 29 & 598,000 & Aug. 1, 1993 \\
\hline 06905500 & Chariton River near Prairie Hill, Mo. (1929-2010) & 34,400 & July 23 & 38,400 & July 27,2008 \\
\hline 06933500 & Gasconade River at Jerome, Mo. (1903-2010) & 44,100 & Oct. 31 & 136,000 & Dec. 5,1982 \\
\hline 06934500 & Missouri River at Hermann, Mo. (1958-2010) & 316,000 & May 17,18 & 750,000 & July 31, 1993 \\
\hline 07019000 & Meramec River near Eureka, Mo. (1904-2010) & 64,500 & Nov. 2 & 145,000 & Dec. 6,1982 \\
\hline 07022000 & Mississippi River at Thebes, Ill. (1933-2010) & 660,000 & Nov. 4 & 996,000 & Aug. 7, 1993 \\
\hline 07057500 & North Fork River near Tecumseh, Mo. (1945-2010) & 17,400 & Oct. 30 & 133,000 & Nov. 19,1985 \\
\hline 07068000 & Current River at Doniphan, Mo. (1921-2010) & 59,700 & Oct. 31 & 122,000 & Dec. 3,1982 \\
\hline
\end{tabular}

a Stations 05587450, 06933500, and 07019000 are streamflow-gaging stations only and not part of the Ambient Water-Quality Monitoring Network (AWQMN).

Table 4. Seven-day low flow for water year 2010, period of record 7-day low flow, and period of record minimum daily mean flow for selected streamgages in Missouri.

[Flow in cubic feet per second]

\begin{tabular}{|c|c|c|c|c|c|}
\hline \multirow{2}{*}{$\begin{array}{c}\text { U.S. Geological } \\
\text { Survey station } \\
\text { number }^{\mathrm{a}}\end{array}$} & \multirow{2}{*}{$\begin{array}{c}\text { Station name } \\
\text { (period of record in water years) }\end{array}$} & \multicolumn{2}{|c|}{$\begin{array}{l}\text { 7-day } \\
\text { low flow }\end{array}$} & \multicolumn{2}{|c|}{$\begin{array}{l}\text { Minimum daily mean flow for } \\
\text { period of record }\end{array}$} \\
\hline & & 2010 & $\begin{array}{l}\text { Period of } \\
\text { record }\end{array}$ & Discharge & Date \\
\hline 05495000 & Fox River at Wayland (1922-2010) & 59 & 0 & 0 & Several years \\
\hline 06820500 & Platte River near Agency (1933-2010) & 116 & 0 & 0 & Several years \\
\hline 06921070 & Pomme de Terre river near Polk (1969-2010) & 8.8 & 0.34 & 0.30 & Aug. 10, 1980 \\
\hline 07016500 & Bourbeuse River near Union (1921-2010) & 64 & 13 & 12 & Oct. 10,1956 \\
\hline 07067000 & Current River at Van Buren (1912-2010) & 889 & 479 & 476 & Oct. 8, 1956 \\
\hline 07187000 & Shoal Creek above Joplin (1942-2010) & 132 & 16 & 15 & Sept. 7, 1954 \\
\hline
\end{tabular}

a Stations 06820500, 07016500, and 07067000 are streamflow-gaging stations only and not part of the Ambient Water-Quality Monitoring Network (AWQMN). 


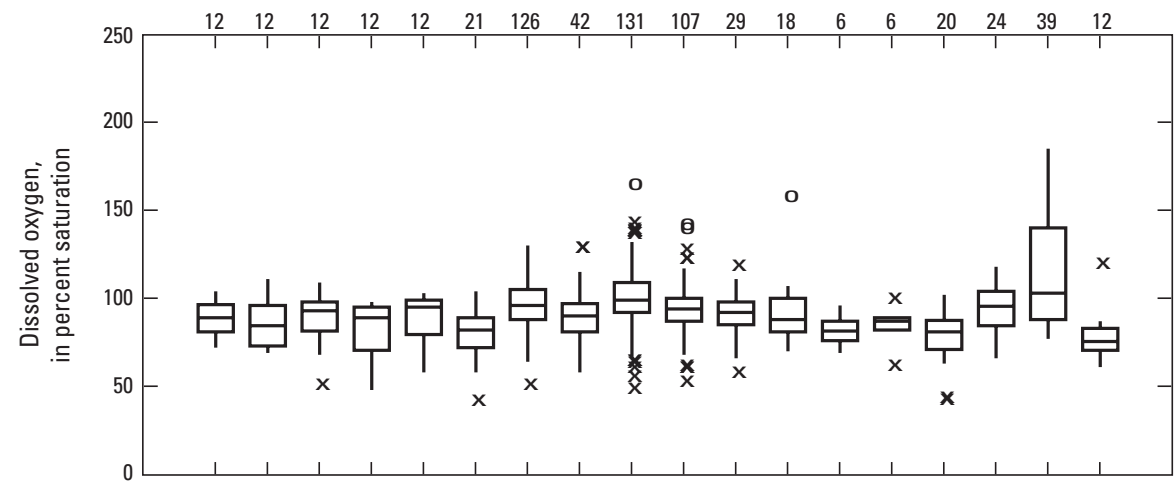

\section{EXPLANATION}

Number of samples

Upper detached

Upper outside

Upper adjacent

75th percentile

Median

25th percentile

Lower adjacent

Lower outside

Lower detached

Laboratory reporting level (LRL) In milligrams per liter (mg/L)
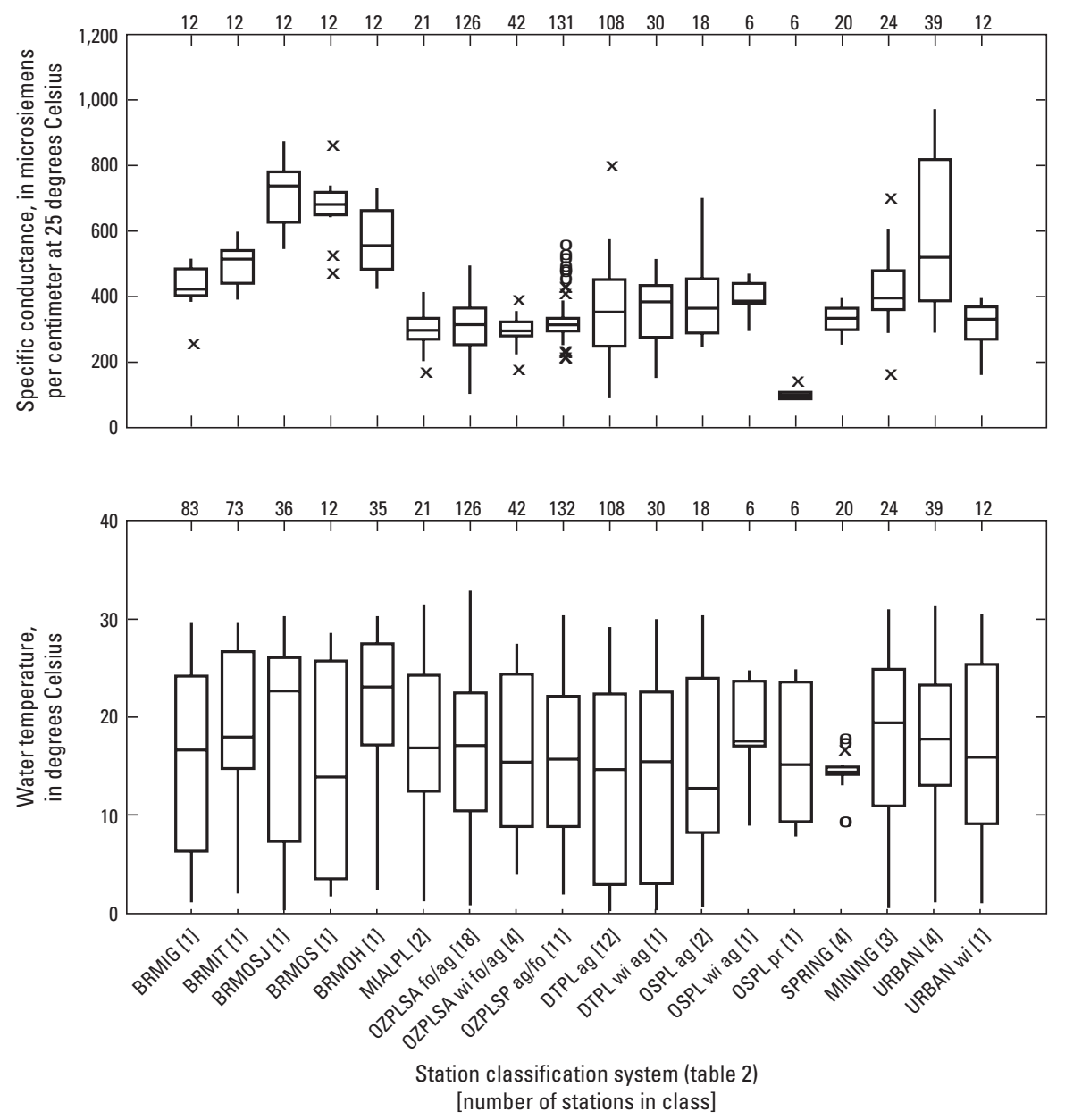

Figure 4. Distribution of physical properties, suspended solids, suspended sediment, and indicator bacteria densities in samples from 72 stations, water year 2010. 

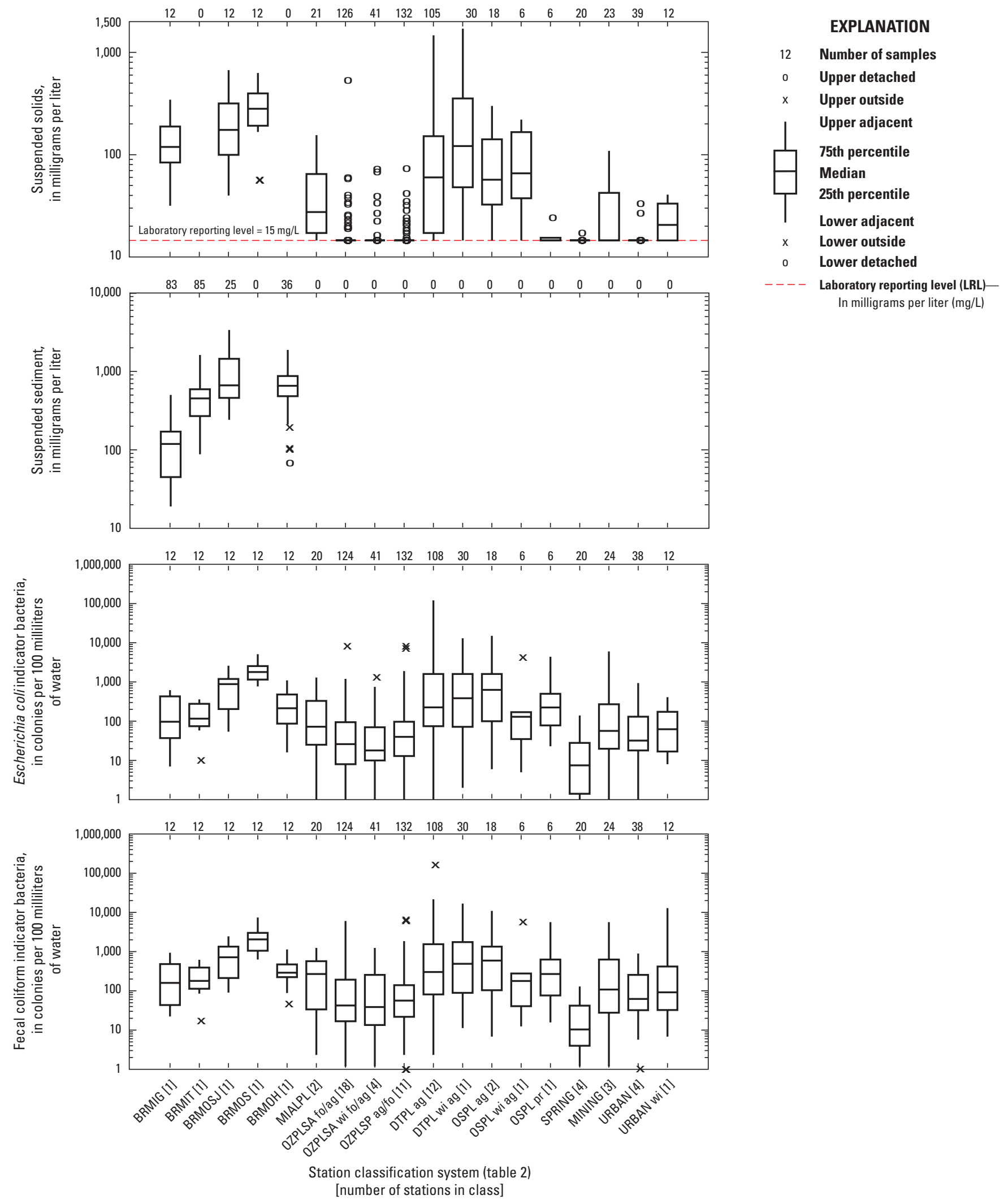

Figure 4. Distribution of physical properties, suspended solids, suspended sediment, and indicator bacteria densities in samples from 72 stations, water year 2010.-Continued 

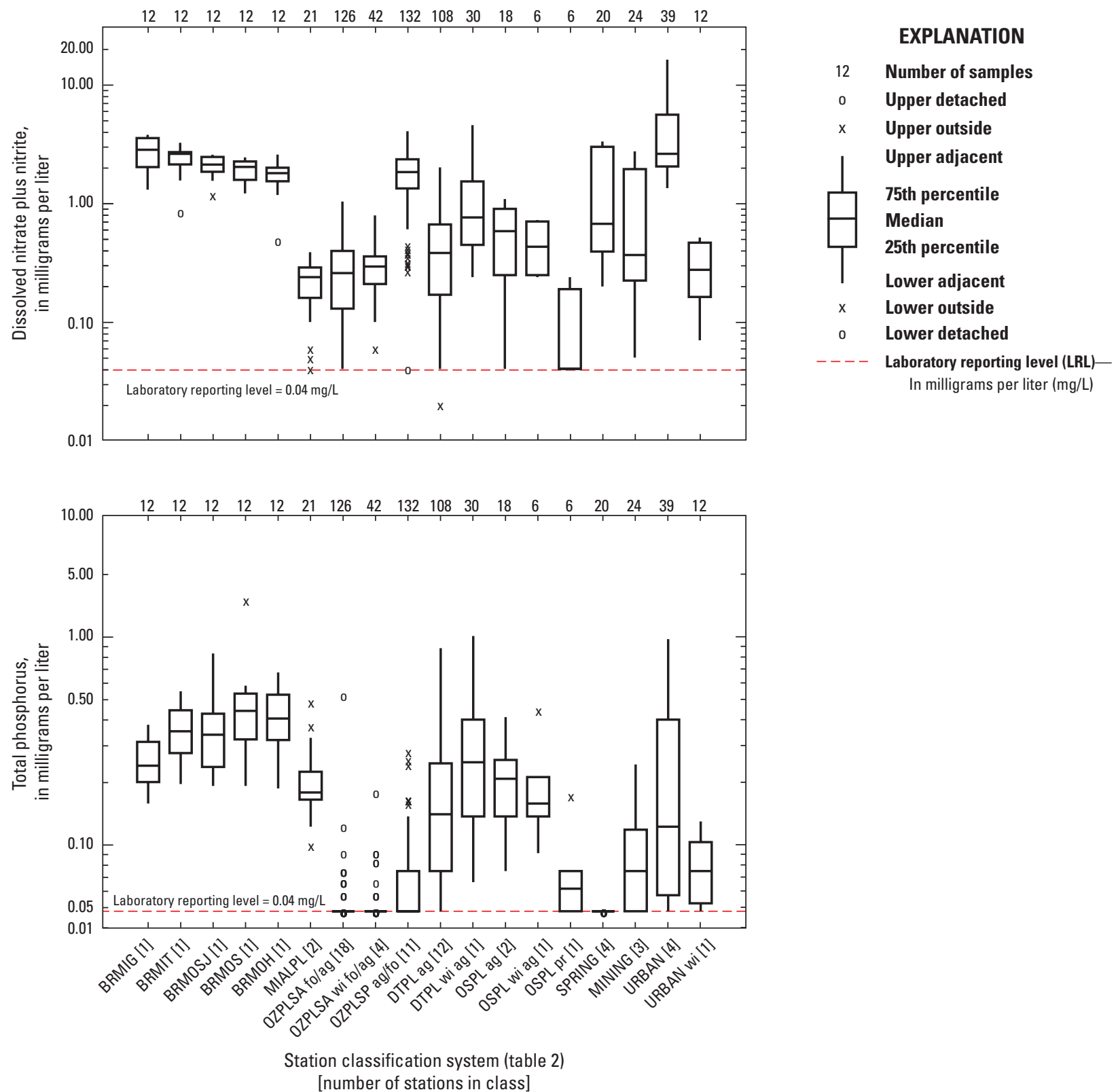

Figure 5. Concentration distribution of dissolved nitrate plus nitrite and total dissolved phosphorus in samples from 72 stations, water year 2010. 

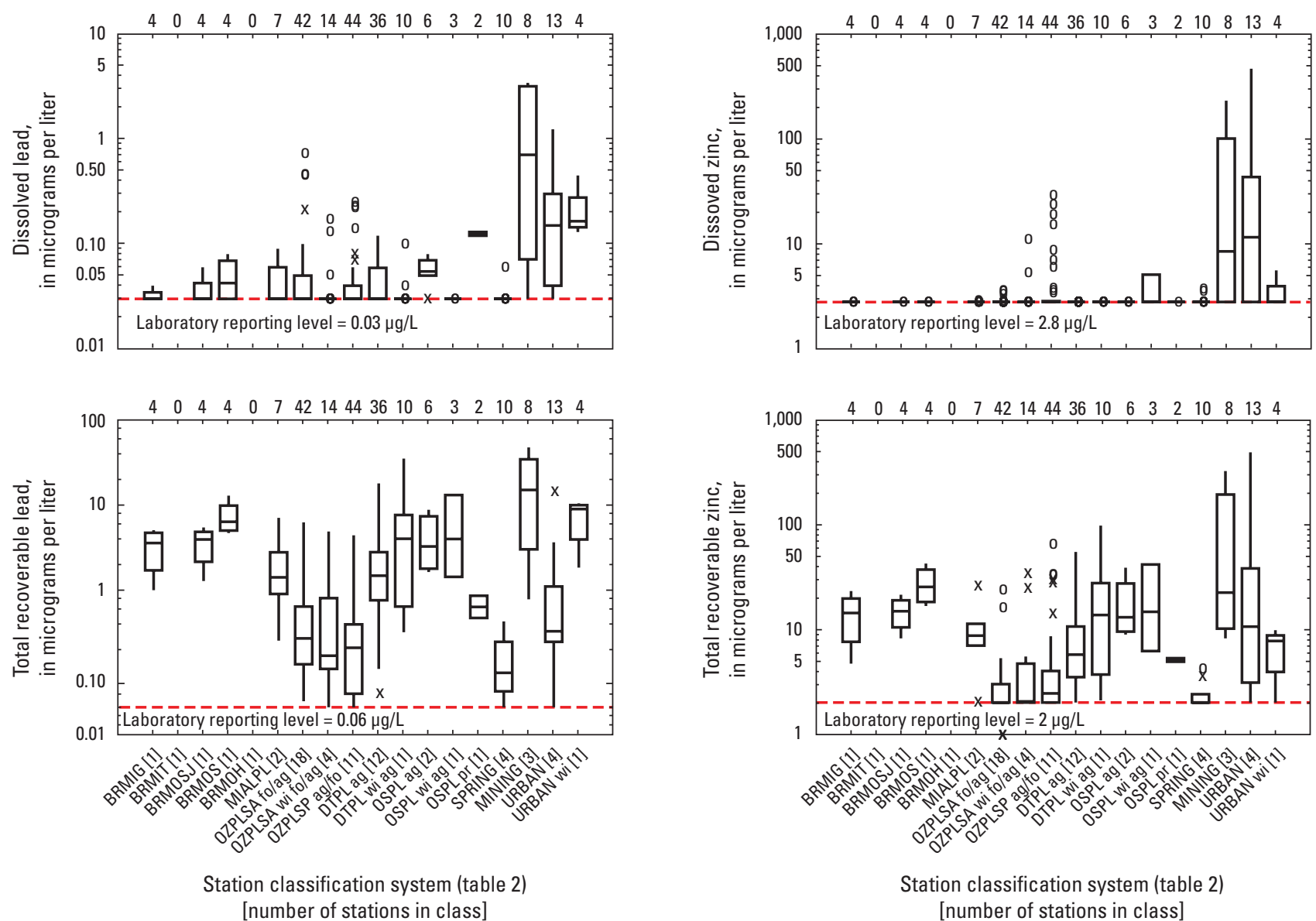

\section{EXPLANATION}

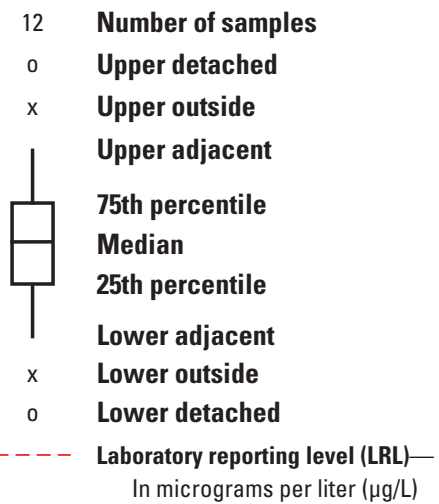

Figure 6. Concentration distribution of dissolved and total recoverable lead and zinc in samples from 72 stations, water year 2010 . 

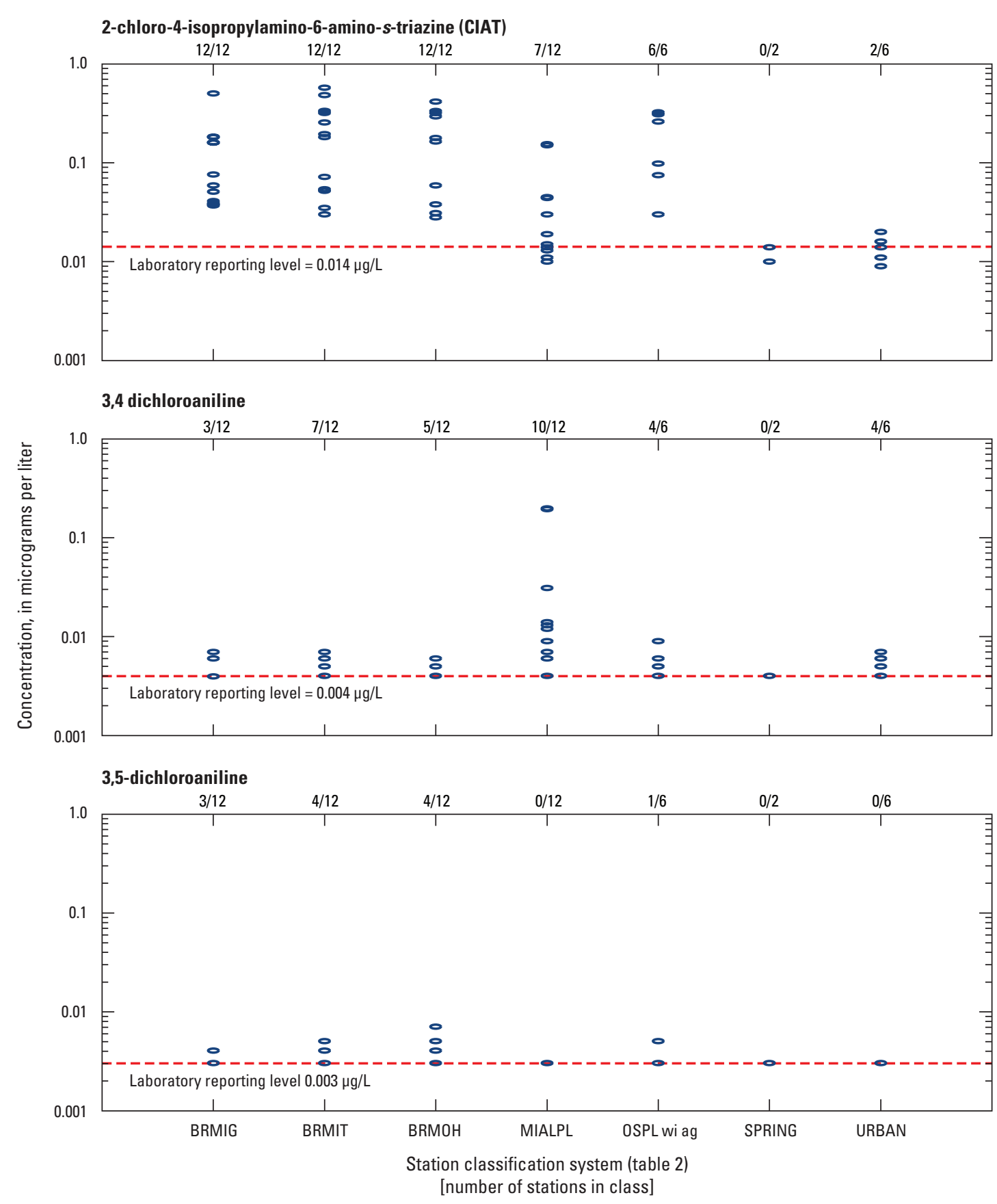

\section{EXPLANATION}

--- Laboratory reporting level (LRL)—In micrograms per liter $(\mu \mathrm{g} / \mathrm{L})$.

Concentrations less than LRL are estimated

- Sample

12/12 Number of detections/total number of samples

Figure 7. Detection of select pesticides from selected stations, water year 2010. 

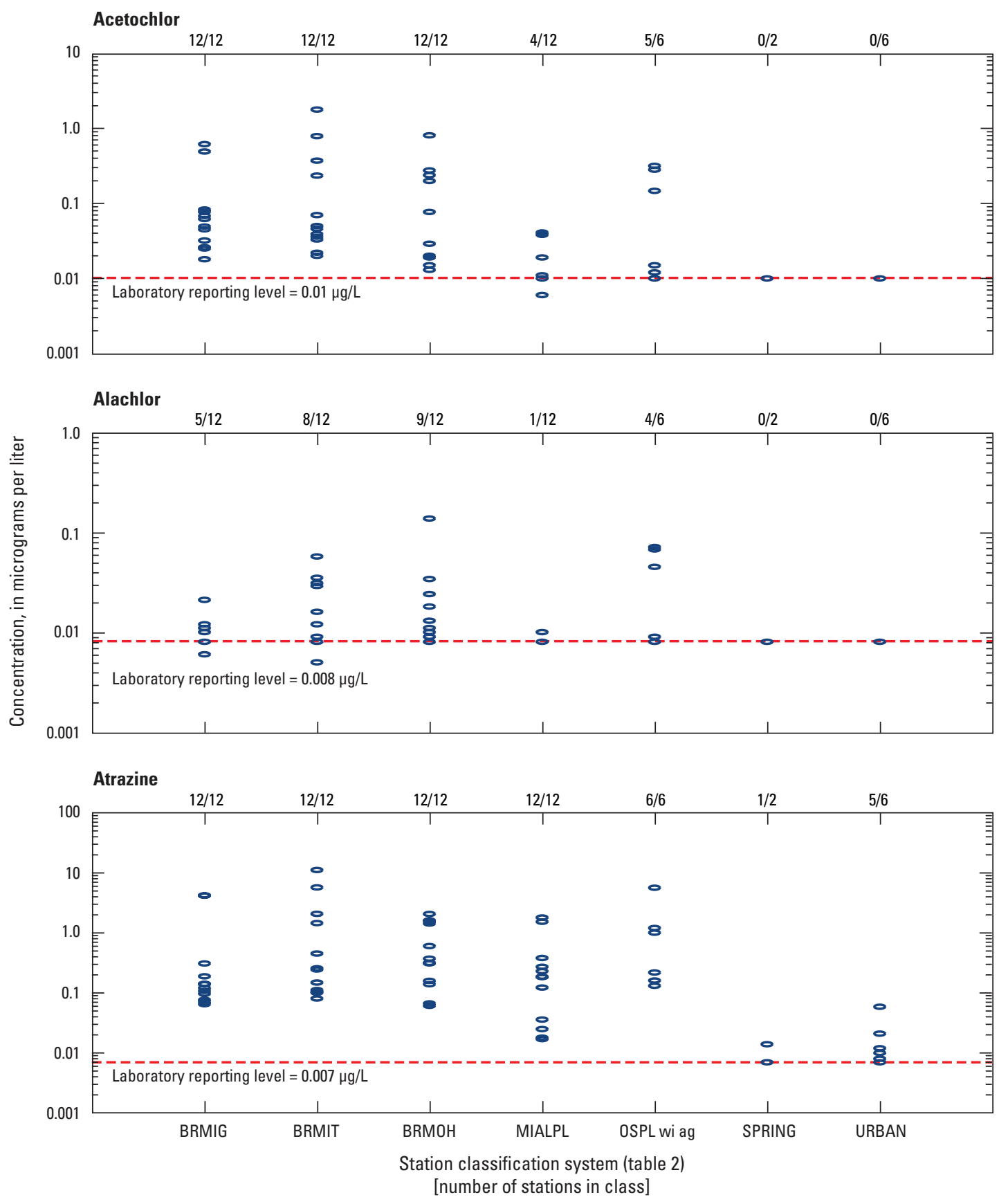

\section{EXPLANATION}

- - - - Laboratory reporting level (LRL) — In micrograms per liter $(\mu \mathrm{g} / \mathrm{L})$. Concentrations less than $\mathrm{LRL}$ are estimated

- Sample

12/12 Number of detections/total number of samples

Figure 7. Detection of select pesticides from selected stations, water year 2010.—Continued 

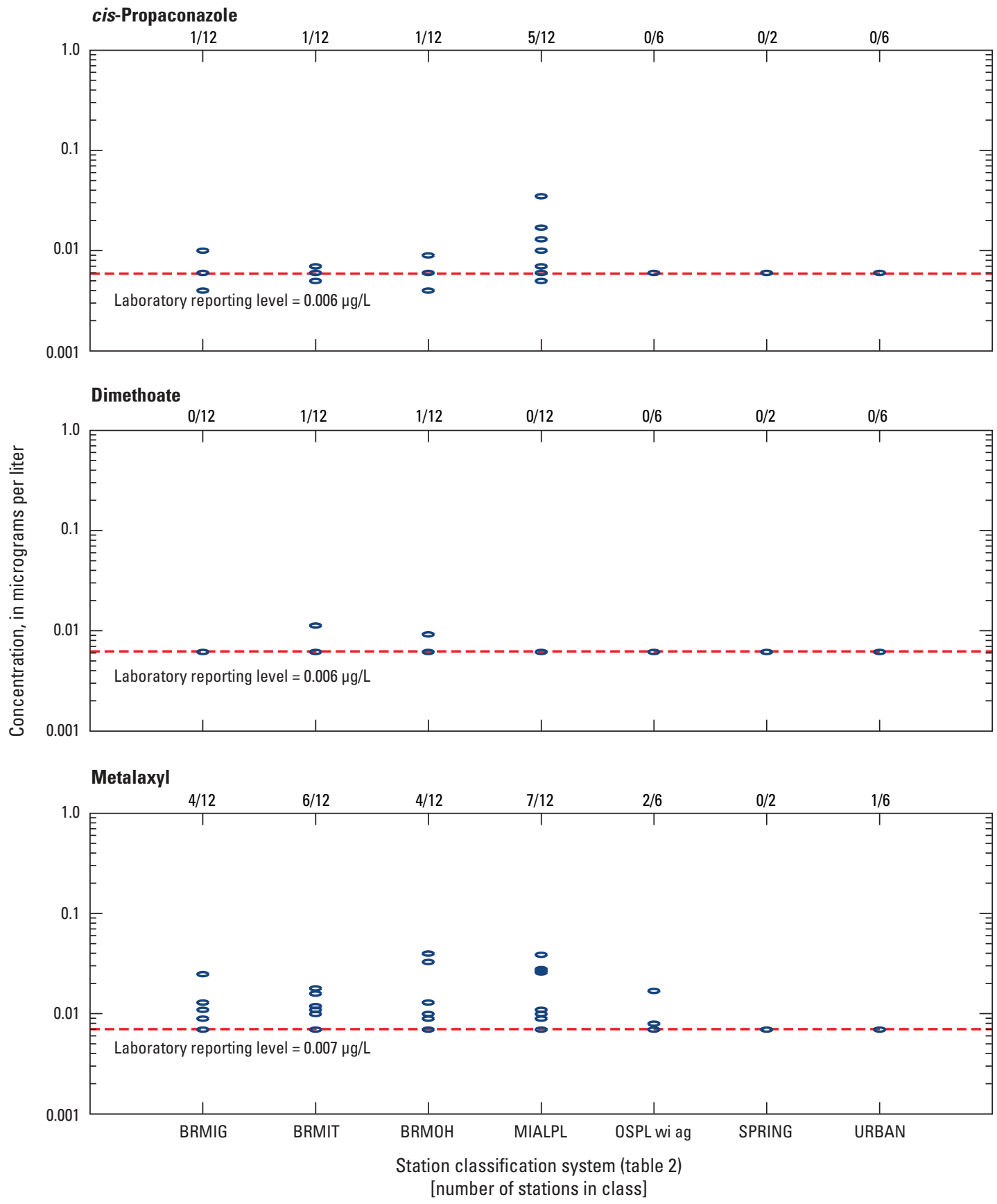

\section{EXPLANATION}

- - - - Laboratory reporting level (LRL) - In micrograms per liter $(\mu \mathrm{g} / \mathrm{L})$.

Concentrations less than $\mathrm{LRL}$ are estimated

- Sample

12/12 Number of detections/total number of samples

Figure 7. Detection of select pesticides from selected stations, water year 2010. - Continued 


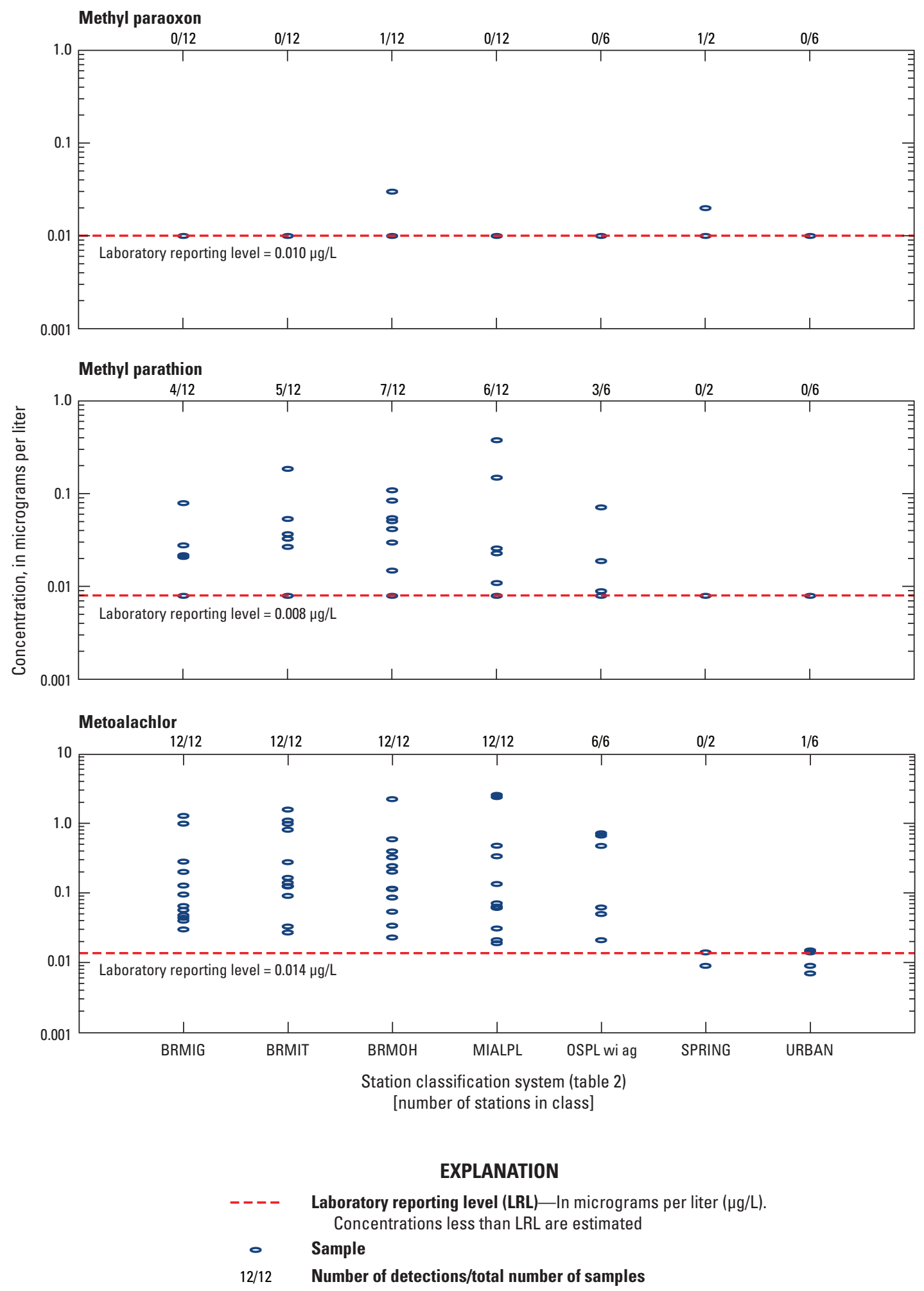

Figure 7. Detection of select pesticides from selected stations, water year 2010. - Continued 


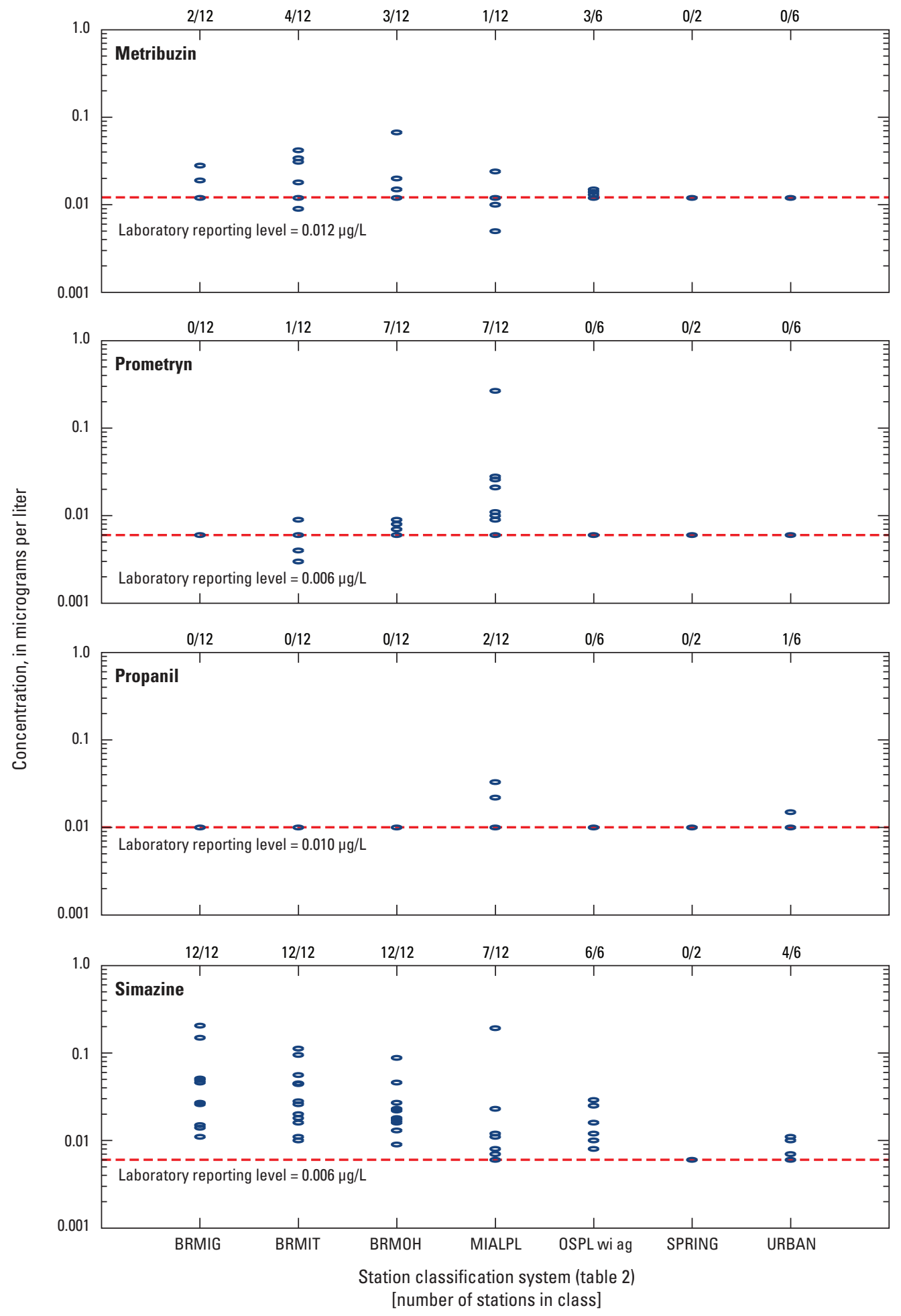

\section{EXPLANATION}

Laboratory reporting level (LRL) — In micrograms per liter ( $\mu \mathrm{g} / \mathrm{L})$.

Concentrations less than $L R L$ are estimated

- Sample

12/12 Number of detections/total number of samples

Figure 7. Detection of select pesticides from selected stations, water year 2010.-Continued 


\section{Distribution of Dissolved Nitrate plus Nitrite and Total Phosphorus Concentrations}

Samples were collected at all stations for the analysis of nutrients, including dissolved nitrate plus nitrite and total phosphorus. Median dissolved nitrate plus nitrite and total phosphorus concentrations varied considerably between all station classes (fig. 5), ranging from less than 0.04 to $2.9 \mathrm{mg} / \mathrm{L}$ nitrate plus nitrite as nitrogen and from less than 0.04 to $0.65 \mathrm{mg} / \mathrm{L}$ total phosphorus as phosphorus. The largest median dissolved nitrate plus nitrite concentrations were detected in samples collected at all Big River (BRMIG having the largest median concentration), OZPLSP ag/fo, and URBAN stations; with the smallest concentrations being detected at OSPL pr (fig. 5). Similarly, median total phosphorus concentrations were among the largest at the Big River (BRMOS having the largest median concentration), MIALPL, DTPL wi ag, OSPL ag, and OSPL wi ag stations. The smallest median total phosphorus concentrations were detected at the OZPLSA (fo/ag and wi fo/ag), OZPLSP ag/fo, and SPRING stations, all of which had median values equal to the LRL (fig. 5).

\section{Distribution of Dissolved and Total Recoverable Lead and Zinc Concentrations}

Samples were collected for the analysis of dissolved and total recoverable trace elements, including lead and zinc. No total recoverable lead and zinc samples were collected at BRMIT and BRMOH. Median concentration ranges of dissolved and total recoverable lead and zinc (fig. 6) were less than 0.03 to 0.71 micrograms per liter $(\mu \mathrm{g} / \mathrm{L})$ dissolved lead; 0.14 to $17.3 \mu \mathrm{g} / \mathrm{L}$ total recoverable lead; less than 2.8 to $11.6 \mu \mathrm{g} / \mathrm{L}$ dissolved zinc; and less than 2 to $26.2 \mu \mathrm{g} / \mathrm{L}$ total recoverable zinc. The largest median concentrations for all four constituents generally were detected in samples collected at MINING, URBAN, and URBAN wi stations; although the Big River (BRMIG, BRMOSJ, and BRMOS) stations also had larger median total recoverable lead and zinc concentrations. The smallest median concentrations of dissolved and total recoverable lead and zinc generally were detected in samples collected at all OZPLSA (fo/ag and wi fo/ag), and SPRING stations (fig. 6). Most stations had median dissolved lead concentrations detected at or less than the LRL except for BRMOS, OSPL ag, OSPL pr, MINING, URBAN and URBAN wi stations.

\section{Concentration and Detection Frequency of Select Pesticides from Selected Stations}

Samples for the analysis of dissolved pesticides were collected at eight stations in the AWQMN, including 3 of the 5 Big River stations (BRMIG, BRMIT, and BRMOH), both stations in the MIALPL, the OSPL wi ag station, 1 SPRING station, and 1 URBAN station. There were 16 compounds detected at concentrations greater than the LRL at 1 or more stations and are presented graphically in this report (fig. 7). The most-frequently detected pesticides were CIAT, acetochlor, alachlor, atrazine, metalaxyl, methyl parathion, metolachlor, and simazine. The concentrations detected at all stations for all pesticides were less than $1.00 \mu \mathrm{g} / \mathrm{L}$ except acetochlor, atrazine, and metolachlor. Acetochlor concentrations ranged from 0.006 to $1.78 \mu \mathrm{g} / \mathrm{L}$. Larger concentrations of acetochlor were detected at the Big River stations (BRMIG, BRMIT, $\mathrm{BRMOH}$ ) . Atrazine concentrations ranged from 0.007 to $11.2 \mu \mathrm{g} / \mathrm{L}$, with the largest concentrations detected at BRMIG, BRMIT, and OSPL wi ag. Metolachlor concentrations ranged from 0.007 to $2.57 \mu \mathrm{g} / \mathrm{L}$, and was detected at concentrations greater than the LRL at all stations except SPRING and URBAN (fig. 7).

\section{References Cited}

Barr, M.N., 2010, Quality of surface water in Missouri, water year 2009: U.S. Geological Survey Open-File Report 2010-1233, 22 p., accessed April 2010, at http://pubs.usgs.gov/of/2010/1233/.

Barr, M.N., and Davis, J.V., 2010, Surface-water quality conditions and long-term trends at selected sites within the ambient water-quality monitoring network in Missouri, water years 1993-2008: U.S. Geological Survey Scientific Investigations Report 2010-5078, 42 p.

Childress, C.J.O., Foreman, W.T., Connor, B.F., and Maloney, T.J., 1999, New reporting procedures based on longterm method detection levels and some considerations for interpretations of water-quality data provided by the U.S. Geological Survey National Water Quality Laboratory: U.S. Geological Survey Open-File Report 99-193, 19 p.

Fenneman, N.M., 1938, Physiography of eastern United States: New York, McGraw-Hill Book Co., Inc., 689 p.

Fishman, M.J., ed., 1993, Methods of analysis by the U.S. Geological Survey National Water Quality Laboratory-Determination of inorganic and organic constituents in water and fluvial sediments: U.S. Geological Survey Open-File Report 93-125, 217 p.

Fishman, M.J., and Friedman, L.C., 1989, Methods for the determination of inorganic substances in water and fluvial sediments: U.S. Geological Survey Techniques of WaterResources Investigations, book 5, chap. A1, 545 p.

Guy, H.P., 1969, Laboratory theory and methods for sediment analysis: U.S. Geological Survey Techniques of WaterResources Investigations, book 5, chap. C1, accessed April 2010 at http://pubs.usgs.gov/twri/twri5c1/. 
Helsel, D.R., and Hirsch R.M., 2002, Statistical methods in water resources: U.S. Geological Survey Techniques of Water-Resources Investigations, book 4, chap. A3, accessed April 2010 at http://pubs.usgs.gov/twri/twri4a3/.

Missouri Department of Natural Resources, 2010a, Missouri water quality report (Section 305(b) Report) November 2010, 97 p.

Missouri Department of Natural Resources, 2010b, Missouri water quality standards - Chapter 7, Water quality: Jefferson City, Mo., Clean Water Commission, 150 p.

Myers, D.N., Stoeckel, D.M., Bushon, R.N., Francy, D.S., and Brady, A.M.G., 2007, Fecal indicator bacteria (ver. 2.0): U.S. Geological Survey Techniques of Water-Resources Investigations, book 9, chap. A7, section 7.1, accessed April 2010 at http://pubs.water.usgs.gov/twri9A7/.

National Oceanic and Atmospheric Administration, 2011a, NOAA National Climatic Data Center, State of the Climate: National Overview for Annual 2010, published online December 2010, accessed May 2011 at $h t t p: / / w w w . n c d c$. noaa.gov/sotc/national/2010/13.

National Oceanic and Atmospheric Administration, 2011b, 2010 Missouri climate summary: National Climatic Data Center database, accessed May 2011 at $h t t p: / / w w w . n c d c$. noaa.gov/oa/climate/research/cag3/mo.html.

Otero-Benítez, W., and Davis, J.V., 2009a, Quality of surface water in Missouri, water year 2007: U.S. Geological Survey Open-File Report 2009-1096, 19 p., accessed April 2010 at http://pubs.usgs.gov/of/2009/1096/.

Otero-Benítez, W., and J.V., Davis, 2009b, Quality of surface water in Missouri, water year 2008; U.S. Geological Survey Open-File Report 2009-1214, 18 p., accessed April 2010 at http://pubs.usgs.gov/of/2009/1214/.

U.S. Census Bureau, 2010, U.S. population estimates, accessed April 2011, at http://www.census.gov/popest/states/ NST-ann-est.html.

U.S. Environmental Protection Agency, 1997, Guidelines for preparation of the comprehensive state water quality assessments (305(b) reports) and electronic updates: Washington, D.C., Office of Water, EPA-841-B97-002A, variously paginated, accessed April 2010 at http://www.epa.gov/ owow/monitoring/guidelines.html.

U.S. Geological Survey, 1964-2005, Water resources dataMissouri: variously paged.

U.S. Geological Survey, 2006, Collection of water samples (ver. 2.0): U.S. Geological Survey Techniques of WaterResources Investigations, book 9, chap. A4, accessed April 2010 at http://pubs.water.usgs.gov/twri9A4.
U.S. Geological Survey, variously dated, National field manual for the collection of water-quality data: U.S. Geological Survey Techniques of Water-Resources Investigations, book 9, chaps. A1-A9, last accessed April 2010 at http://pubs.water.usgs.gov/twri9A.

Wilde, F.D., ed., chapter sections variously dated, Field measurements: U.S. Geological Survey Techniques of WaterResources Investigations, book 9, chap. A6, accessed April 2010 at $h t t p: / / p u b s . w a t e r . u s g s . g o v / t w r i 9 A 6 /$.

Wilde, F.D., Radtke, D.B., Gibs, Jacob, and Iwatsubo, R.T., eds., 2004, Processing of water samples (ver. 2.2): U.S. Geological Survey Techniques of Water-Resources Investigations, book 9, chap. A5, accessed April 2010 at http://pubs.water.usgs.gov/twri9A5/.

Zaugg, S.D., Sandstrom, M.W., Smith, S.G., and Fehlberg, K.M., 1995, Methods of analysis by the U.S. Geological Survey National Water Quality Laboratory-Determination of pesticides in water by $\mathrm{C}-18$ solid-phase extraction and capillary-column gas chromatography/mass spectrometry with selected-ion monitoring: U.S. Geological Survey Open-File Report 95-181, 49 p.

Publishing support provided by: Rolla Publishing Service Center

For more information concerning this publication, contact: Director, USGS Missouri Water Science Center 1400 Independence Road Rolla, MO 65401 (573) 308-3667

Or visit the Missouri Water Science Center Web site at: http://mo.water.usgs.gov 


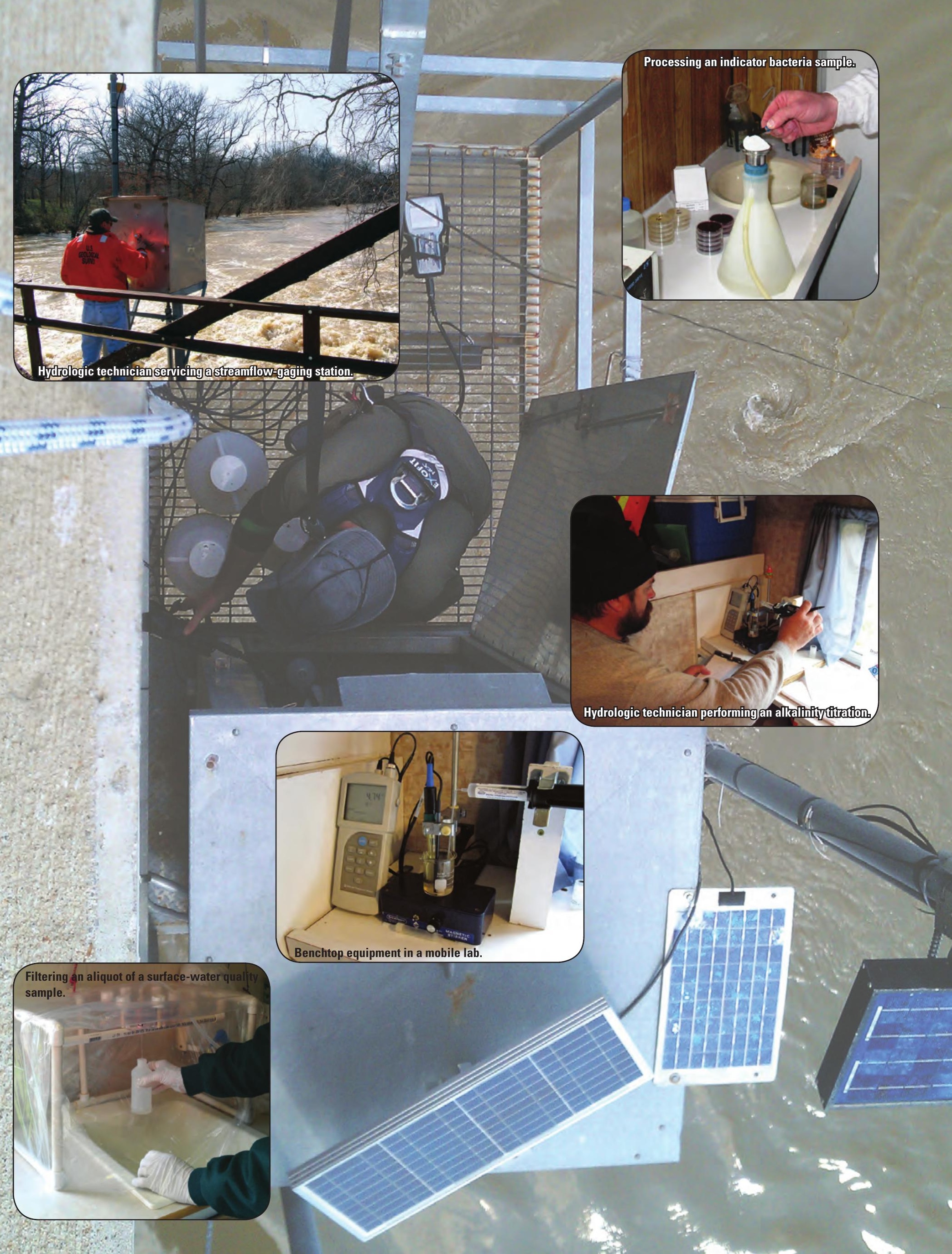





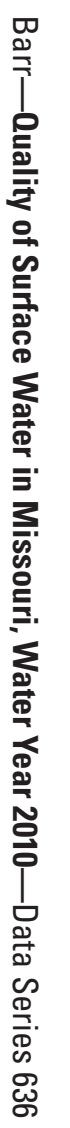

